\title{
Site U1380'
}

\author{
Expedition 334 Scientists $^{2}$
}

\section{Chapter contents}

Background and objectives. ......... 1

Operations.................... 2

Lithostratigraphy and petrology ........ 2

Paleontology and biostratigraphy ....... 3

Structural geology. ............4

Geochemistry and microbiology. ....... 5

Physical properties ............6 6

Paleomagnetism ................ 7

References................

Figures................. 9

Tables...................... 27

\section{Background and objectives}

Integrated Ocean Drilling Program Site U1380 (proposed Site CRIS-10A) was drilled into the middle slope of the Costa Rica margin, $38 \mathrm{~km}$ offshore Osa Peninsula and $24 \mathrm{~km}$ from Caño Island. The site is located along Seismic BGR99 Line 7, at common midpoint $2350\left(8^{\circ} 35.9980^{\prime} \mathrm{N}, 84^{\circ} 4.4037^{\prime} \mathrm{W}\right)$ at 515 meters below sea level (mbsl) (Fig. F1). Site U1380 was the contingency site for Site U1378, and these two sites share the same objectives. The basement at Site U1380 has a thinner sedimentary slope cover than does Site U1378, and the loss in stratigraphic resolution was traded for the easier access to the basement. This site was chosen because it is located above the unlocked portion of the plate boundary, as indicated by interplate earthquake relocation and geodetic measurements (S.L. Bilek, pers. comm., 2003; LaFemina et al., 2009). The temperature at the plate boundary was interpreted to be at least $140^{\circ} \mathrm{C}$ at Site U1380 (Grevemeyer et al., 2004), but more recent modeling implies lower temperatures than previously inferred (i.e., between $60^{\circ}$ and $90^{\circ} \mathrm{C}$; Harris et al., 2010). Within the Costa Rica Seismogenesis Project (CRISP), characterization of the aseismic region of the margin complements characterization of the seismic portion of the plate boundary and above upper plate.

The primary purpose of drilling Site U1380 was to determine the nature, composition, and physical properties of the upper plate basement and to understand the nature of the landward-dipping seismic reflectors that characterize the Costa Rica forearc in the CRISP region. Additional objectives included

- Determining the stress and strain regime of the unlocked portion of the margin,

- Understanding the fluid-flow regime above the high-amplitude reflector interpreted as a fault, and

- Estimating the quantity of tectonically eroded upper plate material.

The margin here consists of upper plate basement underlying slope sediments about $550 \mathrm{~m}$ thick (Fig. F1). The seismic sections show that this site is located above the seaward edge of one of the high-amplitude reflectors interpreted as a displacement surface. Site U1380 was designed to penetrate this reflector.

The seismic interpretation of Site U1380 is based on the prestack depth-migrated section of Seismic BGR99 Line 7 processed by C.R. 
Ranero (Fig. F1). Seismic stratigraphy of the sedimentary slope at Site U1380 shows good continuity of reflection events. The uppermost $100 \mathrm{~m}$ of the slope sediment sequence shows clear horizontal reflections. The underlying $300 \mathrm{~m}$ of sediments grade downward in a more highly reflective zone. The reflectors in this interval gently dip seaward, and the sequence is clearly cut upslope (toward the northeast) by a younger sequence, forming an angular unconformity. The lowermost part of the sedimentary sequence is sharply marked by an irregular, high-amplitude, seaward-dipping reflector interpreted as the top of the upper plate basement. Several landward-dipping, high-amplitude reflectors interpreted as faults cut the surface marking the basement top. At Site U1380, one of these high-amplitude reflectors, interpreted to be a fault, is present at $\sim 800$ meters below seafloor (mbsf). This reflector does not clearly displace the basement top. The velocity increases from $<2 \mathrm{~m} / \mathrm{s}$ in the sediment to $2.8 \mathrm{~m} / \mathrm{s}$ in the fault zone to $>3.3 \mathrm{~m} / \mathrm{s}$ in the basement.

Visual observations and the towed ocean bottom instrument detected several tens of mud mounds and vent communities within a few kilometers of the site (McAdoo et al., 1996; Weinrebe and Ranero, 2003). Many of these structures seem to be related to active faults (Hensen et al., 2004; Ranero et al., 2008). Judging from the continuity of the landward-dipping reflectors interpreted as faults, any fluid advection along these structures originates in areas of at least 4 $\mathrm{km}$ depth.

\section{Operations}

\section{Transit to Site U1380}

After a move in dynamic positioning mode from Site U1378, the vessel stabilized over Site U1380 at 2130 $\mathrm{h}$ (Universal Time Coordinated $-6 \mathrm{~h}$ ) on 6 April 2011. The position reference was a combination of GPS signals and a single acoustic beacon. The positioning beacon was deployed at $2142 \mathrm{~h}$ on 6 April and recovered at $1930 \mathrm{~h}$ on 8 April.

\section{Site U1380}

A single hole was drilled at this site to a depth of 397.0 mbsf (Table T1) with a 97/8 inch rotary core barrel (RCB) core bit with the center bit installed. The center bit was pulled and RCB coring began at 397.0 mbsf. Coring continued through Core 334-U1380A10R to 482.4 mbsf. At that point, it became difficult to circulate and high torque was observed on the top drive. A decision was made to make a wiper trip to remediate the poor hole conditions. It was necessary to pull back from 997.4 to 853.0 meters below rig floor (mbrf) before normal circulation and torque were restored. After attempting to return to bottom from 853.0 mbrf, the bit started taking weight at 920.0 mbrf. High torque and lost circulation made it impossible to return to bottom. At $1500 \mathrm{~h}$, preparations began to abandon Hole U1380A. The core barrel was retrieved and the hole was displaced with 120 bbl of $10.5 \mathrm{ppg}$ mud. Overall core recovery for Site U1380 was $61.6 \%$. Nine cores were recovered after coring $85.4 \mathrm{~m}$. The total length of core recovered at this site was $52.37 \mathrm{~m}$. Hole U1380A was terminated after Core 334-U1380A-10R when hole conditions deteriorated and could not be remediated.

\section{Hole U1380A}

Rig floor operations commenced at $2135 \mathrm{~h}$ on 6 April 2011. The RCB bottom-hole assembly (BHA) was made up with a Rock Bit International C-4 RCB bit and mechanical bit release. The trip to the seafloor was uneventful. The top drive was picked up, the drill string was spaced out, and the hole was spudded at $0215 \mathrm{~h}$ on 7 April. After $19.5 \mathrm{~h}$ of drilling with the center bit installed, the center bit was pulled, and a RCB core barrel was dropped and coring began.

Coring was terminated after Core 334-U1380A-10R when it became impossible to continue advancing. High top drive torque and lost circulation were major factors. A wiper trip was done to try to clean up the hole, but it was impossible to return to bottom and the hole was terminated, plugged, and abandoned.

Total drilled interval was $397.0 \mathrm{~m}$. Total cored interval in Hole U1380A was $85.4 \mathrm{~m}$ with $52.37 \mathrm{~m}$ of core recovered for an RCB system recovery of $61.3 \%$. Last core on deck for Hole U1380A was at $1005 \mathrm{~h}$ on 8 April. After trying to condition the hole for $5.0 \mathrm{~h}$, the decision to abandon the hole was made. The hole was displaced with $10.5 \mathrm{ppg}$ mud, and the drill string was pulled back to $824 \mathrm{mbrf}$ with the top drive in place. The top drive was set back, and the remainder of the drill pipe and BHA were tripped back to the surface. The seafloor was cleared at $1730 \mathrm{~h}$, and the bit cleared the rotary table at $1905 \mathrm{~h}$. The beacon was recovered at $1930 \mathrm{~h}$ and the rig was secured for transit at $2000 \mathrm{~h}$, ending Hole U1380A and Site U1380 on 8 April.

\section{Lithostratigraphy and petrology}

Site U1380 was drilled to investigate the lithostratigraphy of the lower portions of the upper slope sequence and the uppermost portions of the basement imaged in multichannel seismic reflection data. Coring in a single hole from 397 to 474.75 mbsf recovered sediment and sedimentary rocks. The hole was 
terminated above the contact with the basement (as inferred from seismic imaging) because of deteriorating hole conditions. The monotonous sequence of silty clay recovered at Site U1380 is punctuated by widely interspersed centimeter-scale sandy layers and four tephra horizons.

\section{Description of unit}

The $77.75 \mathrm{~m}$ sequence (Cores 334-U1380A-2R through 10R) recovered at Site U1380 is assigned to a single lithostratigraphic unit (Fig. F2).

\section{Unit I}

Interval: 334-U1380A-2R-1 through 10R

Thickness: $77.75 \mathrm{~m}$

Depth: 397-474.75 mbsf

Age: late? Pliocene to late Pleistocene

Lithology: clay(stone), silt(stone), and sand(stone)

Unit I is an olive-green clayey silt(stone) and silty clay(stone) with minor layers of sand(stone), sandy silty clay(stone), clay, clayey silt(stone), and tephra (Fig. F3). The sediment is firm and well consolidated and contains tephra layers that remain unlithified to 449 mbsf (Section 334-U1380A-7R-5). In general, Unit I is massive with minor changes in the proportions of clay, silt, and sand grain sizes occurring gradually over decimeter-scale intervals. Sandy intervals become thicker and more common with depth.

Unit I consists of fining- and coarsening-upward decimeter-scale sequences of sands. In the coarser sand layers, rip-up clasts, rounded clay lenses, and abundant shell fragments are commonly observed. Framboidal pyrite was observed in many of the smear slides throughout Unit I. Shell fragments, diatoms, and nannofossils are sparse but ubiquitous; foraminifers are partly enriched within the sediments and are a major constituent of the sand-sized fraction (especially the sandy silt[stones]).

Unit I is predominantly a terrestrially sourced sequence that is dominated by clay-sized particles. Smear slides indicate that the most common accessory grains in the silt(stone) and clay(stone) include feldspar and lithic (sedimentary and magmatic) fragments. Components present in trace abundances include amphibole, calcite, biotite, chlorite, glass shards, and opaque minerals. The main components in the sandstones are lithic (sediment $>$ magmatic) clasts and feldspar crystals. Biogenic components are rare but include nannofossils, diatoms, and foraminifers.

\section{Tephra layers}

Hole U1380A cores contain four tephra layers intercalated with background Unit I sediment. Individual tephra layers range in thickness from 0.5 to $35 \mathrm{~cm}$. In general, tephra layers have a sharp but unconformable basal contact with the underlying terrigenous sediment but a gradual transitional contact with the overlying tephra-bearing pelagic sediment, and many are normally graded in grain size and well sorted (Fig. F4). All four of the tephra layers have inclined bedding with dip magnitudes $\geq 30^{\circ}$ (see "Structural geology"). The top of one of the tephra layers (interval 334-U1380A-10R-2, 23-37 cm) is bioturbated. The tephra layers are predominantly composed of felsic, white, ash-sized particles ( $>90 \mathrm{vol} \%$ ) containing mainly transparent colorless glass shards with angular blocky, cuspate, flat, and Y-shaped appearance.

With the exception of one tephra layer (interval 334U1380A-5R-5, 29-34 cm), all other tephras show devitrification structures within glass shards and alteration. Grain size ranges from very fine to coarse ash (millimeter size). The mineral assemblages consist of plagioclase, pyroxene (hypersthene and augite), hornblende, and biotite.

\section{Depositional environment and correlation to Sites U1378 and U1379}

The cover sequence recovered from Hole U1380A is a terrestrially sourced upper slope sequence that is consistent with high sediment accumulation rates throughout the depositional interval (see also "Paleontology and biostratigraphy"). The clay-rich deposits of Unit I in Hole U1380A are similar to those observed in Unit II in Holes U1378B and U1379C, although tephra chronologies will be required to correlate among the three sites.

\section{Paleontology and biostratigraphy}

At Site U1380, samples taken from 400-480 mbsf were analyzed for calcareous nannofossils and foraminifers. Calcareous nannofossils provide biostratigraphic control for this section (Table T2). The sediments of the deepest recovered core were tentatively estimated to be lower Pleistocene. Planktonic foraminiferal zones were not established because of the rare occurrences of planktonic foraminifers. Benthic foraminifers reflect continuous, alternating paleoenvironmental changes from an upper to a middle slope environment.

\section{Calcareous nannofossils}

Lower Pleistocene Zone NN19 is observed in the core catcher samples recovered from Hole U1380A. However, the top and bottom boundaries of this zone, de- 
fined by the last occurrence of biostratigraphic markers Pseudoemiliania lacunosa and Discoaster brouweri, respectively, cannot be constrained. With the exception of barren Sample 334-U1380A-7R-CC (452.64 mbsf), calcareous nannofossils occur consistently throughout the section in abundances from few to abundant. Preservation ranges from poor to moderate. Heavy mixing with terrigenous sediments occurs throughout the entire interval. The presence, abundance, and preservation of calcareous nannofossils are presented in Table T3.

Samples 344-U1380A-2R-CC (402.77 mbsf) through 10R-CC (479.73 mbsf) are assigned to Zone NN19 of the lower Pleistocene based on the presence of $P$. $l a$ cunosa and the absence of $D$. brouweri. The dominant species include Helicosphaera carteri, Helicosphaera sellii, Helicosphaera neogranulata/hyalina, Coccolithus pelagicus, and Calcidiscus leptoporus. Sample 7R-CC (452.64 mbsf) is barren of calcareous nannofossils.

\section{Foraminifers}

Generally, foraminiferal abundances are common or rare in the sediment of Hole U1380A. Foraminiferal preservation is moderate or poor, and diagenetically overprinted brown specimens were observed. These trends are similar to the lowermost part of nearby Site U1378. Planktonic foraminifers were analyzed in limited horizons of six core catcher samples (Table T4). Planktonic foraminifers are rare or very rare in this hole and are generally characteristic of tropical fauna such as Globigerinoides quadrilobatus (Globigerinoides sacculifer), Globigerinoides ruber, Orbulina universa, Globorotalia menardii, and Neogloboquadrina dutertrei. Because of the absence of the species commonly used as markers for planktonic foraminiferal biostratigraphy, no zones have been established.

Benthic foraminifers were analyzed in limited horizons of six core catcher samples (Table T2). Benthic foraminiferal abundances in the sediment are common or rare. In general, many of the species of benthic foraminifer observed in the cored sediment are similar to modern assemblages, which are characteristic of the oxygen-minimum zone (100-1000 mbsf) of the seafloor in this region. The detected faunas include many species similar to those of nearby Site U1378. Samples contain Bolivina argentea, Epistominella smithi, Uvigerina peregrina, Cibicidoides mckannai, and Gyroidina, which are characteristic of upper to middle bathyal (200-500 mbsl) paleoenvironments.

\section{Structural geology}

The primary structural geology objective during Expedition 334 was to describe and document style, ge- ometry, and kinematics of structural features observed in the cores. Site U1380 was cored in the interval 397-477 mbsf and potentially corresponds to the lower succession cored in Hole U1378B. Only one lithostratigraphic unit has been defined at this site (see "Lithostratigraphy and petrology"). Bedding dips are shallow to moderate, with a mean of $\sim 40^{\circ}$. Two fault zones have been identified at $407-$ 419 and $454-477$ mbsf that consist of relatively intense faulting and fractured and brecciated zones. These zones show both normal and reverse sense of shear. Brecciated zones are $10-20 \mathrm{~cm}$ thick and are associated with fracture zones. No paleomagnetic data were available to restore structural data to true geographic coordinates.

\section{Structures in slope sediments}

\section{Bedding}

Bedding planes were recognized as boundary surfaces in thin layers of sand and ash within a clayey silt and silty clay sequence. Bedding was also recognized as thin laminations in sediments. Bedding dips are shallow to moderate, ranging from $27^{\circ}$ to $49^{\circ}$ (Fig. F5).

\section{Brittle faults}

Faults recognized in the cores from Site U1380 are characterized by striated and/or polished surfaces or by offset markers. The slip sense is determined by offset markers such as lamination, bioturbation, and slickensteps on striated slip surfaces. Incohesive faults show both normal and reverse displacement sense (Fig. F5). Unfortunately, no paleomagnetic data were available to perform rotations of structures to true geographic coordinates. However, we plan to conduct paleomagnetic corrections postexpedition.

\section{Healed faults and sediment-filled veins}

Two healed faults occur between 397.3 and 398.8 mbsf (Fig. F5). The cohesiveness of the healed fault surfaces may indicate early stage soft-sediment deformation. These healed faults have moderate to relatively steep dip angles $\left(43^{\circ}\right.$ and $\left.51^{\circ}\right)$. Two sets of sediment-filled veins were identified in a $2.2 \mathrm{~m}$ interval from 417.2 to 419.4 mbsf. The sediment-filled veins are aligned in arrays parallel or subparallel to the bedding planes, as observed in the cores from Holes U1378B and U1379C (see "Structural geology" in the "Site U1378" chapter [Expedition 334 Scientists, 2012b] and "Structural geology" in the "Site U1379" chapter [Expedition 334 Scientists, 2012c]). Sediment-filled veins form a variety of structures, many of which have been identified during previous ocean drilling expeditions. This category of 
structures includes the sigmoidal-shaped suite of thin, mud-filled veins that are slightly darker than the surrounding materials and that were first documented by Ogawa (1980) and Cowan (1982). Dark veins are spaced at regular intervals $(0.5-2.0 \mathrm{~mm})$ in the horizontal plane.

\section{Fractured and brecciated zones}

Fractured zones are defined as moderately sheared zones fractured into few centimeter-sized fragments. Brecciated zones are intensively sheared zones composed of few millimeters to $1 \mathrm{~cm}$ sized angular fragments (Fig. F6). Each fragment has an angular shape with straight and parallel striation on its surfaces. For the most part, these features are distinguishable from drilling-induced fractures and fragments (see "Structural geology" in the "Methods" chapter [Expedition 334 Scientists, 2012a]).

Fault zones shown in Figure F5 are characterized by alternating sequences of fractured and brecciated zones (Fig. F6), which are always terminating through a weakly fractured zone in the undisturbed host rock below. Two fault zones have been identified at 407.3-419.4 and 453.8-477.7 mbsf (Fig. F5). The upper fault zone consists of a fractured zone and 0.1$0.3 \mathrm{~m}$ thick brecciated zones close to the uppermost and lowermost boundaries of the fault zone. The lower fault zone consists of fractured zones and three $\sim 0.4 \mathrm{~m}$ thick brecciated zones.

\section{Geochemistry and microbiology Geochemistry}

We collected 10 whole-round samples in Hole U1380A for pore fluid analysis at a frequency of one sample per core, except for Core 334-U1380-3R, from which we took an additional sample for helium analyses. All the samples were exposed to the atmosphere prior to squeezing, but the sample for helium analyses was processed in a helium-free environment (see "Geochemistry and microbiology" in the "Methods" chapter [Expedition 334 Scientists, 2012a]). Because of time constraints, we focused our efforts on collecting samples for postcruise studies and only a limited number of analyses were carried out onboard. A total of nine headspace (HS) samples were collected for safety monitoring and were analyzed on the gas chromatograph-flame ionization detector on the natural gas analyzer (NGA). In addition, eight void gas samples (VAC) were collected. Four gas samples preserved with $10 \% \mathrm{KCl}$ solution (NZ) were also sampled for shipboard analysis. All of these samples were measured using the NGA. The data reported are from the HS and NZ samples. The inorganic and or- ganic geochemistry data are listed in Tables T5 and T6 and are plotted in Figures F7, F8, and F9.

Salinity, $\mathrm{Cl}$, and $\mathrm{Na}$ concentrations follow the same trends with depth observed at Site U1378, indicating diffusional communication with fluids at depth (Figs. F7). The low chloride concentration and salinity reflect significant freshening, with values as low as $380 \mathrm{mM}$ and $20(\sim 60 \%-67 \%$ of seawater value), respectively (Fig. F7).

Methane concentration ranges between 3,347 and $11,926 \mathrm{ppmv}$ in pore fluids from sediment sampled between 398.1 and 475.1 mbsf in Hole U1380A (Fig. F8). The gas at these depths is thermogenic in origin, as indicated by the low ratios of methane to heavier homologs (ethane and propane), with $\mathrm{CH}_{4} /\left(\mathrm{C}_{2} \mathrm{H}_{6}+\right.$ $\mathrm{C}_{3} \mathrm{H}_{8}$ ) ratios ranging from 458.78 to 551.80 (Fig. F9). The $\mathrm{C}_{2} \mathrm{H}_{6}$ concentrations range between 3.89 and 15.69 ppmv, with the highest concentration at 475.1 mbsf. Propane is also present in the cores with concentrations ranging from 1.39 to $7.33 \mathrm{ppmv}$ at depth. Iso- and $n$-butane are detected from 398.1 to 475.1 mbsf, with concentrations between 0.55 and 3.45 ppmv. Iso-pentane concentrations range from 0.64 to 2.34 ppmv. Propane, butane, and pentane concentrations were all highest at $475.1 \mathrm{mbsf}$.

At Site U1378, pore fluid chemical profiles suggest the presence of a unique fluid between 420 and 500 mbsf characterized by relatively low salinity, $\mathrm{Cl}, \mathrm{Mg}$, $\mathrm{K}$, and alkalinity and elevated $\mathrm{Ca}$ concentrations (Figs. F7; data plotted in blue). This depth interval also corresponds to a marked increase in thermogenic hydrocarbons (propane, $n$-butane, and iso-butane; Figs. F19, F20 in the "Site U1378" chapter [Expedition 334 Scientists, 2012b]). These anomalies are not present within the interval cored at Site U1380 (Figs. F7; data plotted in red). A clear offset exists in the $\mathrm{Ca}, \mathrm{Mg}, \mathrm{K}, \mathrm{NH}_{4}$, and alkalinity profiles at $\sim 400$ 500 mbsf between Sites U1380 and U1378. Ca and $\mathrm{NH}_{4}$ concentrations at Site U1380 are lower than at Site U1378, whereas K, Mg, and alkalinity concentrations are higher at Site U1380. Ca, Mg, and K concentrations were determined twice by inductively coupled plasma-atomic emission spectroscopy at both Sites U1380 and U1378, and $\mathrm{NH}_{4}$ and alkalinity concentrations were determined by different methods; therefore, the offset is not an analytical artefact. Site U1380 is $\sim 1 \mathrm{~km}$ northeast of Site U1378, and the lithostratigraphy at Site U1378 is only partially represented at Site U1380 (see Fig. F4 in "Site U1378" chapter [Expedition 334 Scientists, 2012b]; Fig. F2). The interval between $\sim 400$ and 500 mbsf at Site U1378 contains more and thicker sections of coarser grained sediments than at Site U1380, indicating that these horizons are either not present at Site U1380 or were not recovered and sampled. It is likely 
that these coarser grained horizons are the conduits for the laterally migrating fluids observed at Site U1378 (see "Geochemistry and microbiology" in the "Site U1378" chapter [Expedition 334 Scientists, 2012b]), which may explain why the geochemical profiles at Site U1380 show a steady increase (Ca and $\mathrm{NH}_{4}$ ) or decrease ( $\mathrm{Mg}$ and $\mathrm{K}$ ) through the depth cored and do not display the marked anomalies observed at Site U1378.

\section{Microbiology}

No whole rounds were collected for microbiology at Site U1380.

\section{Physical properties}

At Site U1380, physical properties measurements provide basic information characterizing lithostratigraphic units. After sediment cores reached thermal equilibrium with ambient temperature at $\sim 20^{\circ} \mathrm{C}$, gamma ray attenuation (GRA) density, magnetic susceptibility, and $P$-wave velocity were measured on whole-round core sections using the Whole-Round Multisensor Logger (WRMSL). After WRMSL scanning, the whole-round sections were logged for natural gamma radiation (NGR). Thermal conductivity was measured using the full-space method on sediment cores and the half-space method on split lithified sediment cores. A photo-image-capture logger and a color spectrophotometer were used to collect images of the split surfaces of the archive-half cores on the Section Half Image Logger and Section Half Multisensor Logger (SHMSL), respectively. Discrete $P$ wave measurements were made on cubes subsampled from split sediment cores on the Section Half Measurement Gantry (SHMG). Moisture and density (MAD) were measured on discrete subsamples collected from the working halves of the split sediment cores.

\section{Density and porosity}

Bulk density values at Site U1380 were determined from both GRA measurements on whole cores and mass/volume measurements on discrete samples from the working halves of split cores (see "Physical properties" in the "Methods" chapter [Expedition 334 Scientists, 2012a]). Samples were chosen from relatively undisturbed portions and preferentially from clay sediments rather than silty or sandier sections. A total of 38 discrete samples were analyzed for MAD.

In general, wet bulk density values determined from whole-round GRA measurements agree with measurements from discrete samples (Fig. F10A). Wet bulk density values are relatively constant through the cored interval. The mean and standard deviation are 1.87 and $0.05 \mathrm{~g} / \mathrm{cm}^{3}$, respectively.

Grain density measurements were determined from mass/volume measurements on discrete samples. Values are relatively constant with depth, with an average value of $2.69 \mathrm{~g} / \mathrm{cm}^{3}$ and increasing variability with depth (Fig. F10B). The mean and standard deviation are 2.67 and $0.08 \mathrm{~g} / \mathrm{cm}^{3}$, respectively. These values suggest a terrigenous composition.

Porosity values (see "Physical properties" in the "Methods" chapter [Expedition 334 Scientists, 2012a]) were determined from mass/volume measurements on discrete samples using MAD Method C. Porosity is relatively constant through the cored interval at $49 \%$ (Fig. F10C).

\section{Magnetic susceptibility}

Volumetric magnetic susceptibilities were measured using the WRMSL and point measurements were made on the SHMSL for all recovered cores from Site U1380. Uncorrected values of magnetic susceptibility are presented in Figure F11. Magnetic susceptibility values measured with these two methods are in good agreement, although point measurements show much greater scatter. In general, magnetic susceptibility in the sedimentary sequence is low, indicating an abundance of non-iron-bearing clays. Whole-core magnetic susceptibility values are relatively constant through the cored interval, with a mean value of 0.028 SI.

\section{Natural gamma radiation}

NGR results are reported in counts per second (cps; Fig. F12). NGR counting intervals were $\sim 10$ min per whole-core interval. Despite the short counting time, NGR counts are considered reliable and have a mean and standard deviation of 19 and 3 cps, respectively.

\section{$P$-wave velocity}

Unconfined measurements of $P$-wave velocity at Site U1380 were determined from measurements on sediment whole cores and on discrete samples from the working halves of sediment split cores (see "Physical properties" in the "Methods" chapter [Expedition 334 Scientists, 2012a]). No reliable whole-core $P$ wave velocity measurements were made (Fig. F13). Only three reliable discrete sample measurements of $P$-wave velocity were made with the SHMG along the $z$-axis. The mean of these values is $1581 \mathrm{~m} / \mathrm{s}$. Based on visual inspection of the cores, the unreliable measurements are attributed to the low water content of the clays. The $P$-wave signal does not seem to penetrate through relatively dry clays. Comparisons be- 
tween these measurements and empty core liners suggest that the signal travels within the plastic liner around the core instead of through the recovered material, resulting in unrealistically low velocities.

\section{Thermal conductivity}

Thermal conductivity measurements were conducted on split cores using the half-space method (see "Physical properties" in the "Methods" chapter [Expedition 334 Scientists, 2012a]). Thermal conductivity is relatively constant through the cored interval, with a mean and standard deviation of 1.05 and $0.22 \mathrm{~W} /(\mathrm{m} \cdot \mathrm{K})$, respectively (Fig. F14).

\section{Color spectroscopy}

Color reflectance measurement results are presented in Figure F15. $L^{*}$ values are generally between 10 and $50 . a^{*}$ and $b^{*}$ values are inversely correlated. $a^{*}$ values are generally between -5 and 5 and those of $b^{*}$ generally vary from -10 to 5 .

\section{Paleomagnetism}

Remanent magnetization was measured on archivehalf cores and on discrete samples taken from the working half recovered in Hole U1380A. All archivehalf cores were demagnetized in an alternating field (AF) to $15 \mathrm{mT}$ and measured with the pass-through superconducting rock magnetometer (SRM), whereas discrete samples were subjected to stepwise AF demagnetization and measured in both the SRM and JR6 magnetometer. Two discrete samples were subjected to stepwise thermal demagnetization.

\section{Natural remanent magnetization}

Behavior of natural remanent magnetization (NRM) during paleomagnetic measurements was relatively uniform at Site U1380 compared to Holes U1378A and U1379C investigated during this expedition. All cores were drilled using the RCB system. Apparently, the drilling-induced remagnetization still exists in the recovered cores (Fig. F16), as evidenced by inclinations steeper than the value expected from the latitude of the site. However, the characteristics of the remagnetization are different from those observed in extended core barrel (XCB) cores at previous sites. NRM has no preferred declinations and shows slightly shallower inclination $\left(\right.$ mean $=\sim 45^{\circ}$ ) than those of XCB cores from other Expedition 334 sites. From 470 to 480 mbsf in Core 334-U1380-10R, however, inclinations are much steeper $\left(\sim 70^{\circ}-80^{\circ}\right)$, indicating perhaps a different type of barrel was used to core these sediments and/or the steep inclinations are affected by the fairly steep bedding dips (see
"Structural geology"). The mean NRM intensity is $\sim 10-3 \mathrm{~A} / \mathrm{m}$ and exhibits no significant variations downhole.

\section{Demagnetization behavior}

For the pass-through measurements of the archive halves, AF demagnetization up to $15 \mathrm{mT}$ was not effective to recover primary remanence magnetization. Inclination only shifted to slightly toward shallower values but still seems to be dominated by the nearvertical drilling induced remagnetization (Fig. F16). Declination values for each measurement interval are relatively stable during the demagnetization. NRM intensity decreased by approximately one order of magnitude after $15 \mathrm{mT}$ AF demagnetization (Fig. F16B).

AF demagnetization experiments of discrete samples revealed rapid removal of a near-vertical overprint at low demagnetization steps. After this, many discrete samples showed complicated demagnetization paths that did not simply go toward the origin (Fig. F17). Although some part of those demagnetization paths may represent primary magnetizations, we cannot resolve them at this point. Several discrete samples displayed more straightforward demagnetization behavior (Fig. F17). The number of samples from recovered cores is too limited to confidently define the magnetic polarity for the cores from Site U1380.

To evaluate the thermal behavior and identify magnetic mineralogy, we also conducted thermal demagnetization on two selected discrete samples. Heating was conducted using a thermal demagnetizer (Schonstedt TSD-1), and magnetization was measured using the SRM (see "Paleomagnetism" in the "Methods" chapter [Expedition 334 Scientists, 2012a]). Samples 334-U1380A-7R-4, 23-25 cm, and $8 \mathrm{R}-1,95-97 \mathrm{~cm}$, were heated from $75^{\circ}$ to $300^{\circ} \mathrm{C}$ at $25^{\circ} \mathrm{C}$ increments. As shown in Figure F18A and F18B, these two samples have very low unblocking temperatures. By $125^{\circ} \mathrm{C}$ demagnetization, $>60 \%$ of NRM intensity has been lost, suggesting the possible presence of goethite. Thermal demagnetization on Sample 334-U1380A-7R-41, 23-25 cm, successfully removed the drilling-induced component (Fig. F18C), but it is not obvious for Sample 8R-1, 95-97 $\mathrm{cm}$ (Fig. F18D). After $150^{\circ} \mathrm{C}$ demagnetization, the characteristic remanent magnetization component is evident from the demagnetization paths, with a fair amount of scatter (Fig. F18). Judging by the unblocking temperature $\left(150^{\circ}-200^{\circ} \mathrm{C}\right)$, titanomagnetite or maghemite may be the magnetic carriers for these two samples. Compared with AF demagnetization results, it appears that thermal demagnetization is not effective in isolating the primary remanence for samples recovered in Hole U1380. 


\section{References}

Cowan, D.S., 1982. Origin of "vein structure" in slope sediments on the inner slope of the Middle America Trench off Guatemala. In Aubouin, J., von Huene, R., et al., Init. Repts. DSDP, 67: Washington, DC (U.S. Govt. Printing Office), 645-650. doi:10.2973/dsdp.proc.67.132.1982

Expedition 334 Scientists, 2012a. Methods. In Vannucchi, P., Ujiie, K., Stroncik, N., Malinverno, A., and the Expedition 334 Scientists, Proc. IODP, 334: Tokyo (Integrated Ocean Drilling Program Management International, Inc.). doi:10.2204/iodp.proc.334.102.2012

Expedition 334 Scientists, 2012b. Site U1378. In Vannucchi, P., Ujiie, K., Stroncik, N., Malinverno, A., and the Expedition 334 Scientists, Proc. IODP, 334: Tokyo (Integrated Ocean Drilling Program Management International, Inc.). doi:10.2204/iodp.proc.334.103.2012

Expedition 334 Scientists, 2012c. Site U1379. In Vannucchi, P., Ujiie, K., Stroncik, N., Malinverno, A., and the Expedition 334 Scientists, Proc. IODP, 334: Tokyo (Integrated Ocean Drilling Program Management International, Inc.). doi:10.2204/iodp.proc.334.104.2012

Grevemeyer, I., Kopf, A.J., Fekete, N., Kaul, N., Villinger, H.W., Heesemann, M., Wallmann, K., Spiess, V., Gennerich, H.-H., Muller, M., and Weinrebe, W., 2004. Fluid flow through active mud dome Mound Culebra offshore Nicoya Peninsula, Costa Rica: evidence from heat flow surveying. Mar. Geol., 207(1-4):145-157. doi:10.1016/j.margeo.2004.04.002

Harris, R.N., Spinelli, G., Ranero, C.R., Grevemeyer, I., Villinger, H., and Barckhausen, U., 2010. Thermal regime of the Costa Rican convergent margin: 2 . Thermal models of the shallow Middle America subduction zone offshore Costa Rica. Geochem., Geophys., Geosyst., 11(12):Q12S29. doi:10.1029/2010GC003273

Hensen, C., Wallmann, K., Schmidt, M., Ranero, C.R., and Suess, E., 2004. Fluid expulsion related to mud extru- sion off Costa Rica-a window to the subducting slab. Geology, 32(3):201-204. doi:10.1130/G20119.1

LaFemina, P., Dixon, T.H., Govers, R., Norabuena, E., Turner, H., Saballos, A., Mattioli, G., Protti, M., and Strauch, W., 2009. Fore-arc motion and Cocos Ridge collision in Central America. Geochem., Geophys., Geosyst., 10(5):Q05S14. doi:10.1029/2008GC002181

McAdoo, B.G., Orange, D.L., Silver, E.A., McIntosh, K., Abott, L., Galewsky, J., Kahn, L., and Protti, M., 1996. Seafloor structural observations, Costa Rica accretionary prism. Geophys. Res. Lett., 23(8):883-886. doi:10.1029/ 96GL00731

Ogawa, Y., 1980. Beard-like veinlet structure as fracture cleavage in the Neogene siltstone in the Miura and Boso Peninsulas, central Japan. Sci. Rep. Dept. Geol., Kyushu Univ., 13:321-327.

Ranero, C.R., Grevemeyer, I., Sahling, U., Barckhausen, U., Hensen, C., Wallmann, K., Weinrebe, W., Vannucchi, P., von Huene, R., and McIntosh, K., 2008. Hydrogeological system of erosional convergent margins and its influence on tectonics and interplate seismogenesis. Geochem., Geophys., Geosyst., 9(3):Q03S04. doi:10.1029/ 2007GC001679

Weinrebe, W., and Ranero, C.R. (Eds.), 2003. FS/RV Sonne Cruise Report SO173/2: Seduction, Part A. Seismogenesis and tectonic erosion during subduction: Middle America margin. GEOMAR Rep., 116. http://oceanrep.geomar.de/13407/1/Geomar-Report-116.pdf

Zijderveld, J.D.A., 1967. AC demagnetization of rocks: analysis of results. In Collinson, D.W., Creer, K.M., and Runcorn, S.K. (Eds.), Methods in Palaeomagnetism: New York (Elsevier), 254-286.

Publication: 12 April 2012

MS 334-105 
Figure F1. Detail of poststack time-migrated Seismic BGR99 Line 7 centered at Site U1380. CMP $=$ common midpoint. Thick red line indicates cored and recovered interval.

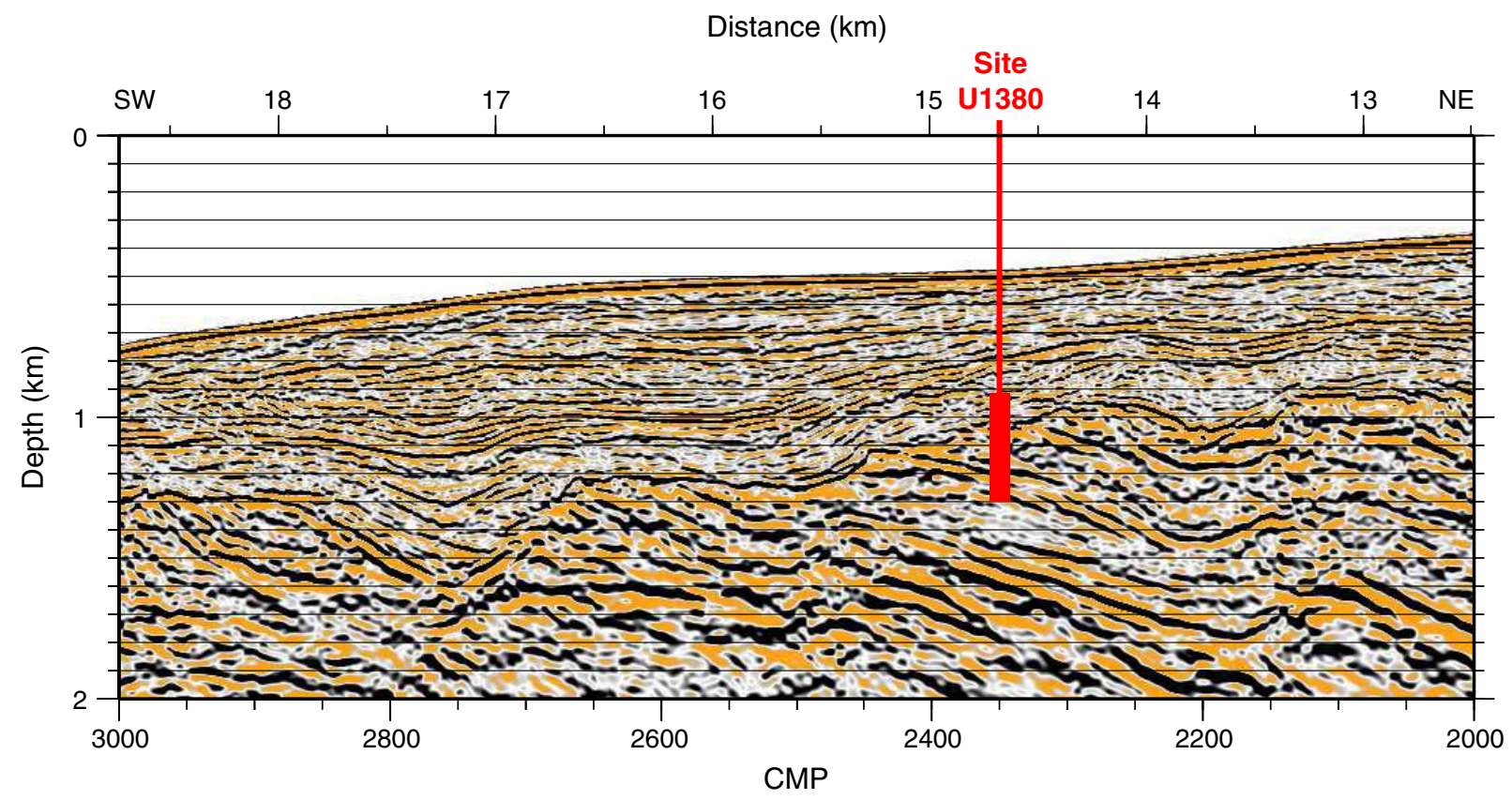


Figure F2. Graphic summary log, Hole U1380A.

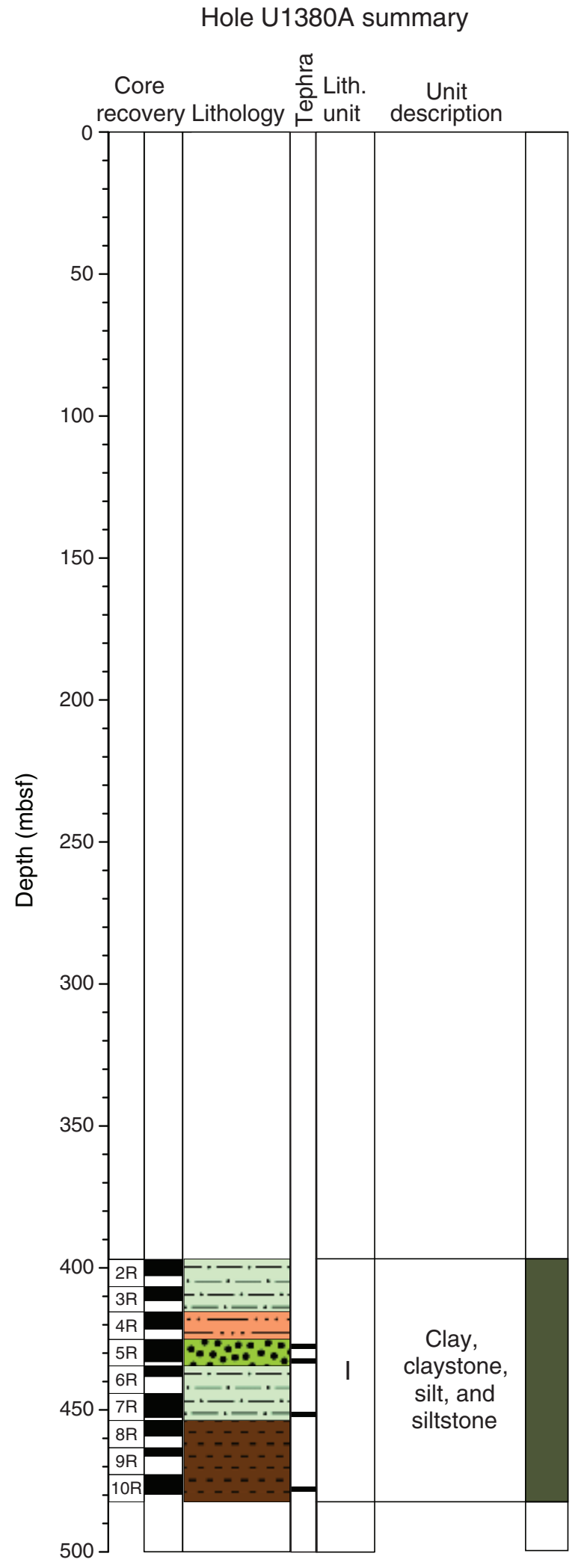


Figure F3. Representative core image of Unit I with typical homogeneous dark olive-green silty clay (interval 334-U1380A-8R-2, 53-75 cm).

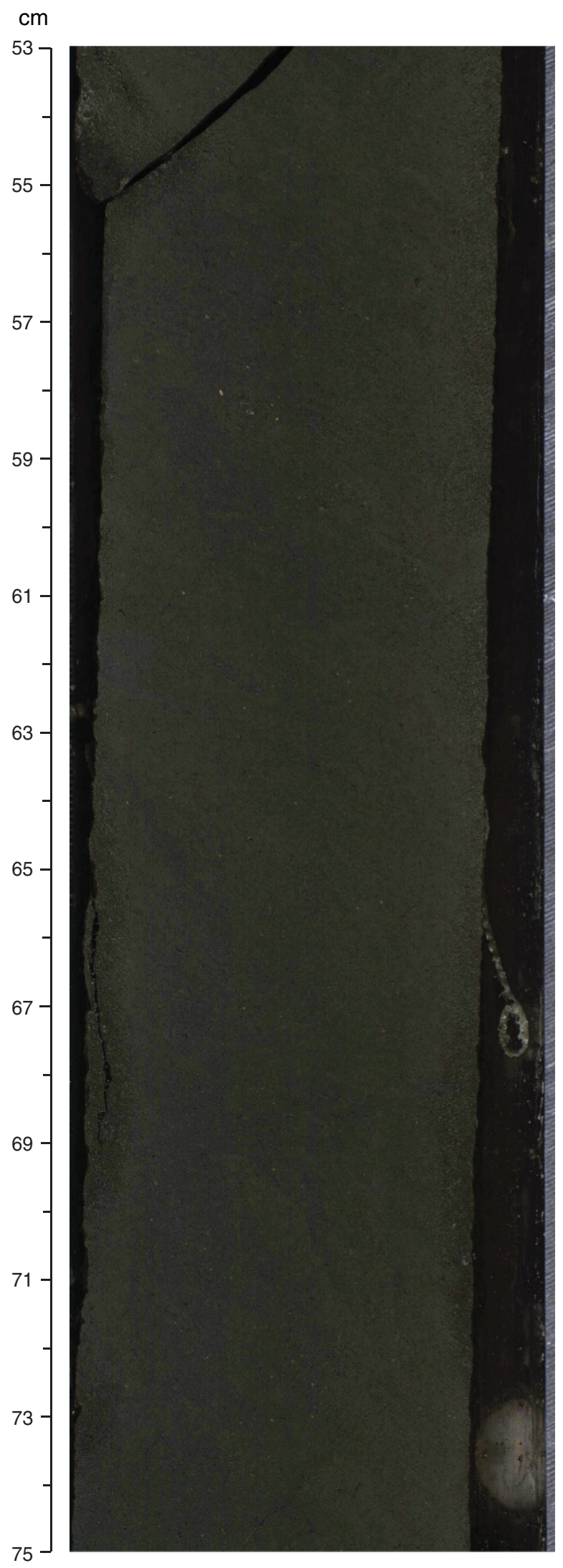


Figure F4. Core image of an inclined pinkish gray tephra layer with normal gradation from medium ash at the base to fine ash at the top. The interval from 22 to $23 \mathrm{~cm}$ is intensely bioturbated (interval 334-U1380A-10R-2, $20-40 \mathrm{~cm})$.

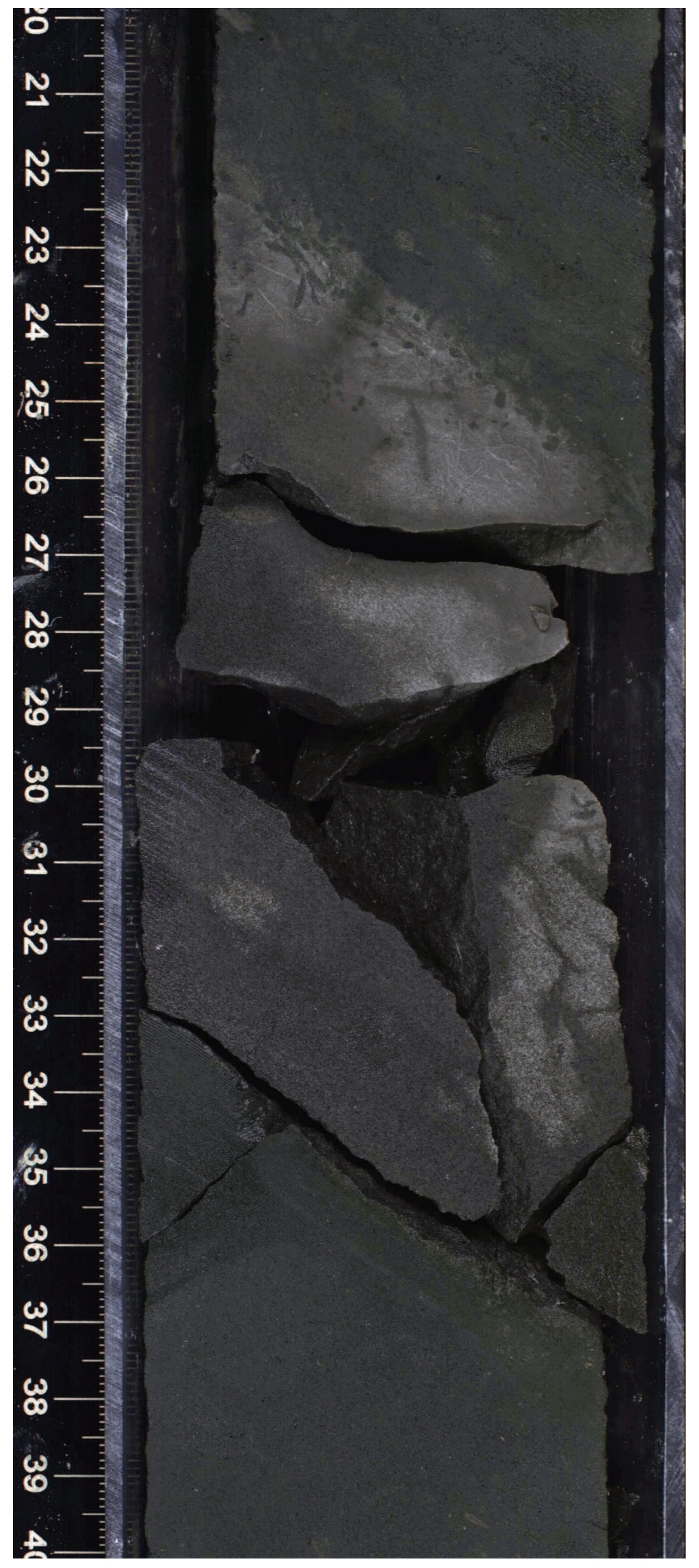


Figure F5. Plot of bedding dips, faults, and fractures as a function of depth, Site U1380. Shaded areas indicate fault zones.

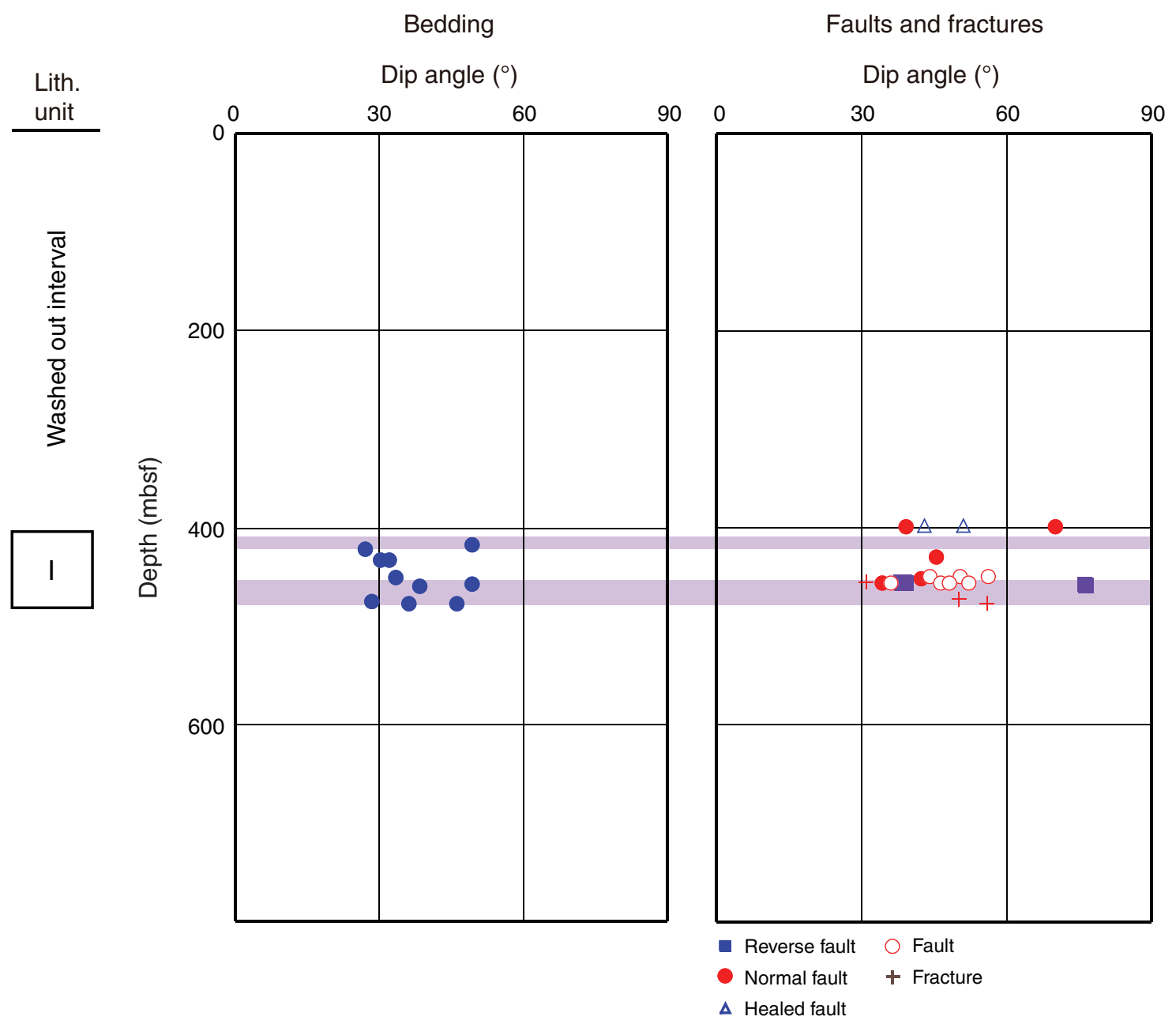


Figure F6. Photograph of fractured and brecciated zones in the lower fault zone between 453.8 and $477.7 \mathrm{mbsf}$, Hole U1380A. Note the dominant fragment size $(<1 \mathrm{~cm})$ within the brecciated zone and the larger fragments within the fractured zone.

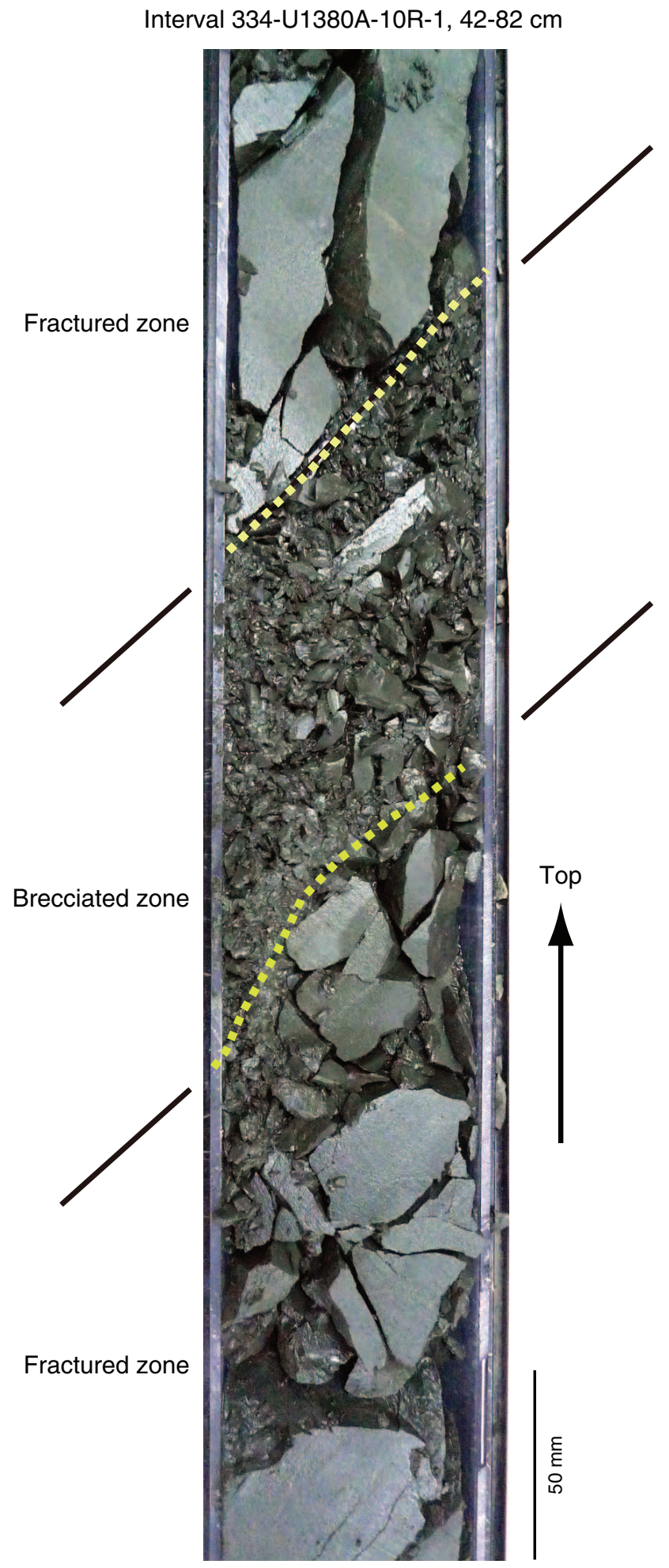


Figure F7. Concentration-depth profiles of salinity, chlorinity, calcium, magnesium, sodium, potassium, alkalinity, and ammonium, Sites U1378 (blue) and U1380 (red).
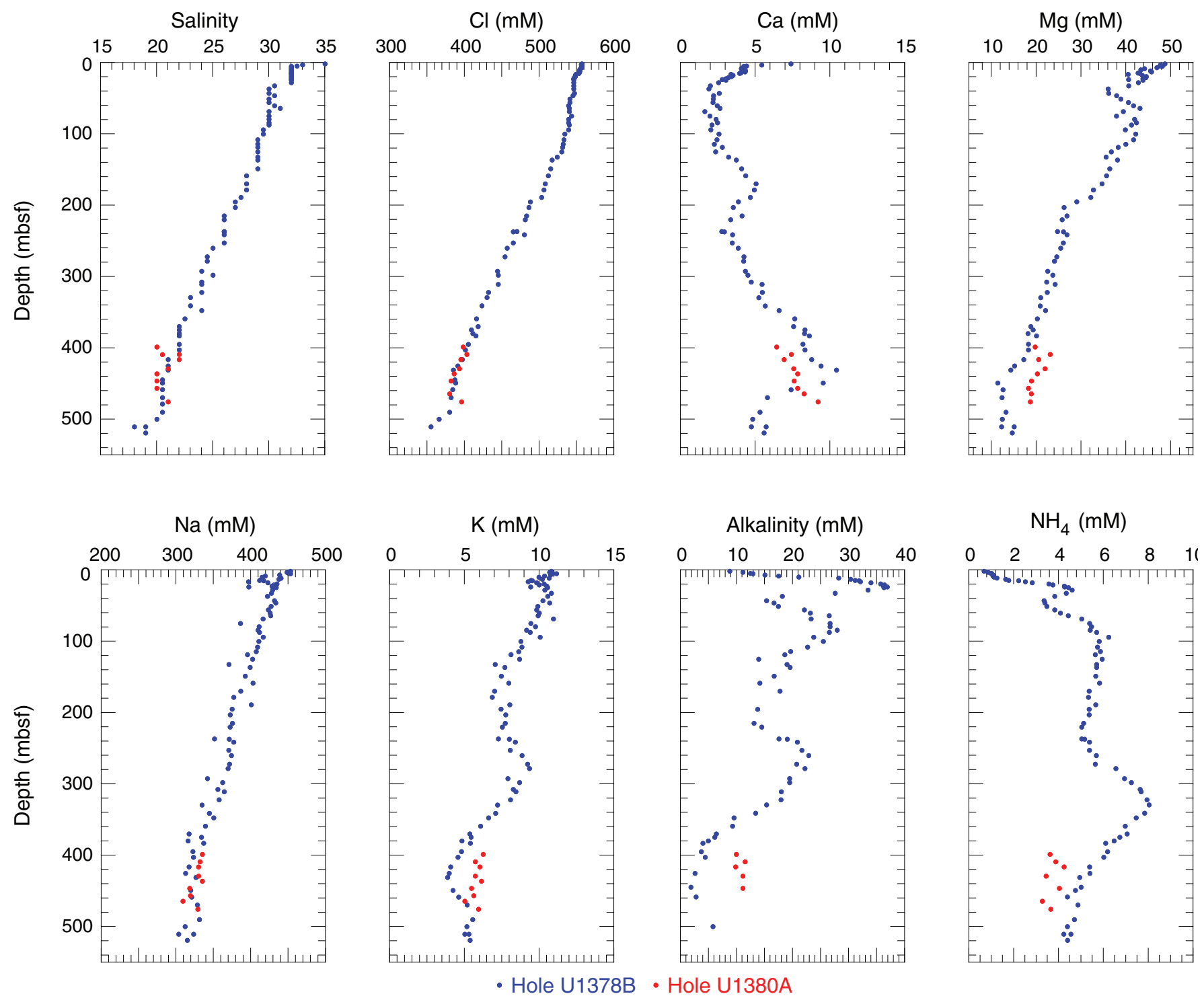

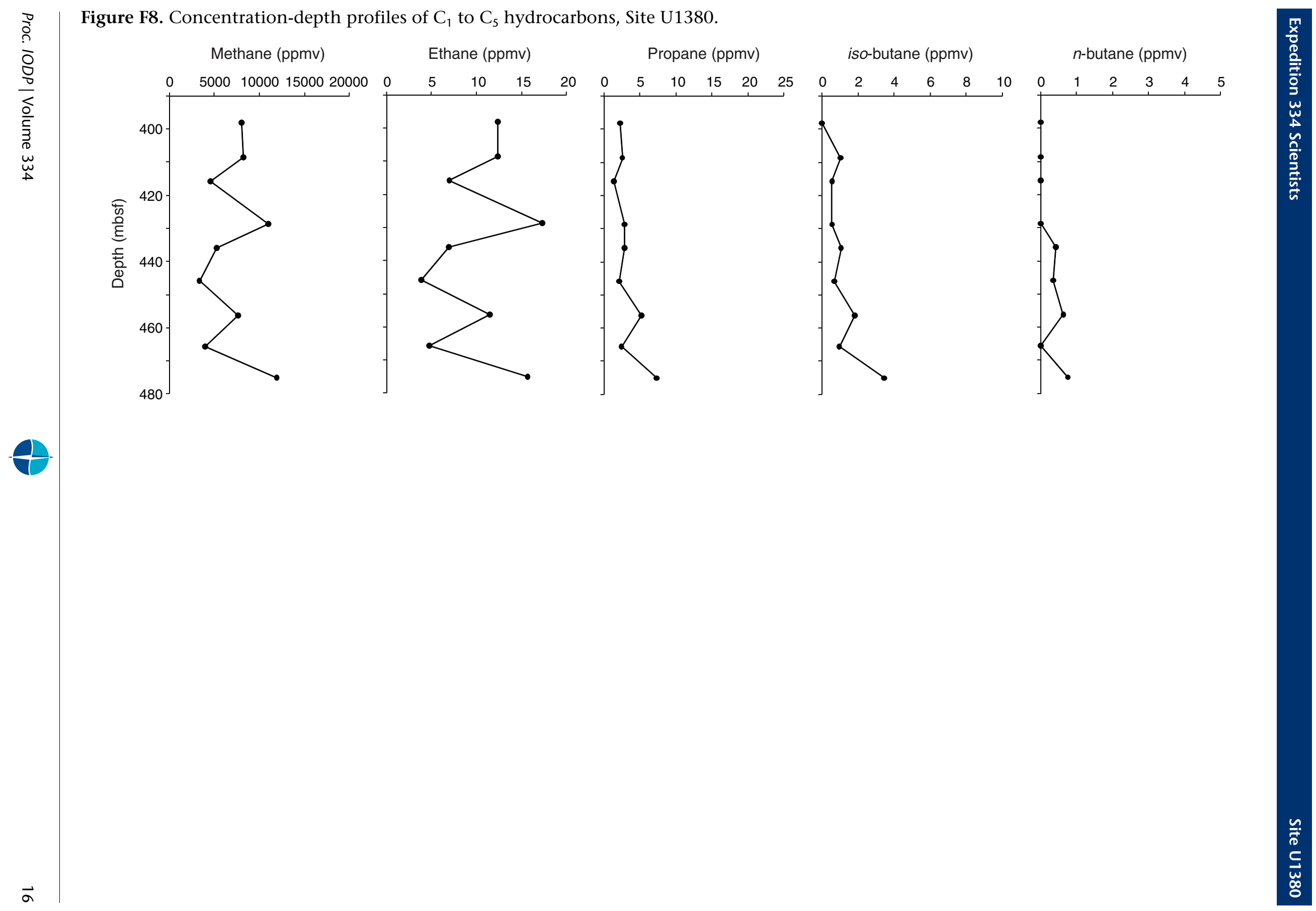
Figure F9. Depth profile of $\mathrm{CH}_{4} /\left(\mathrm{C}_{2} \mathrm{H}_{6}+\mathrm{C}_{3} \mathrm{H}_{8}\right)$, Site U1380.

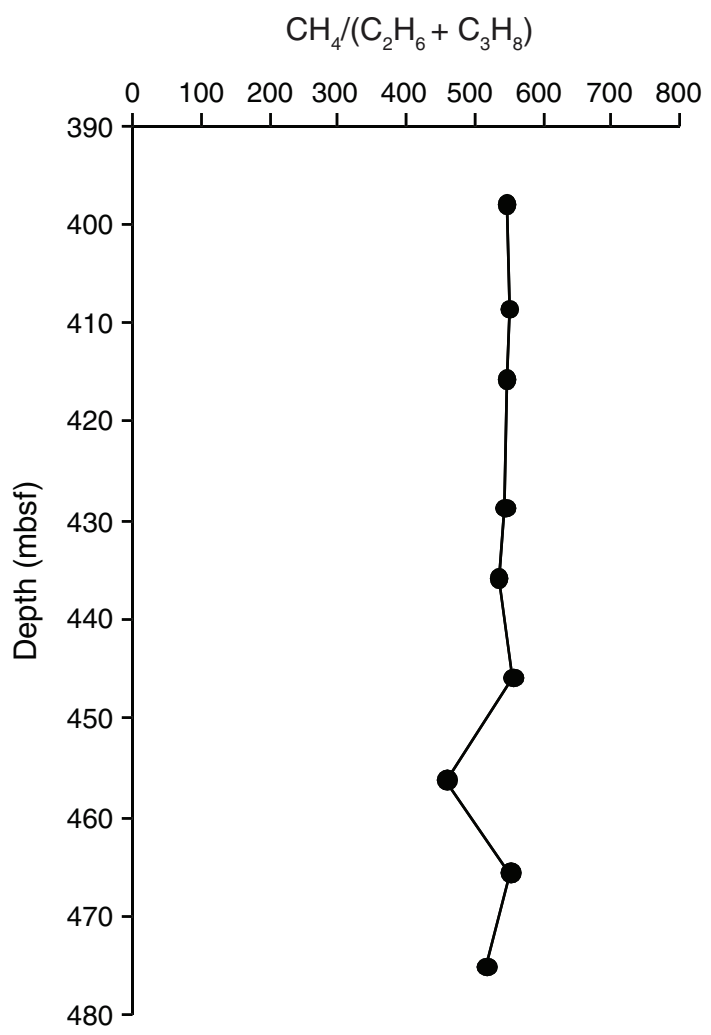


Figure F10. Plots of combined results of density and porosity measurements, Site U1380. A. Gamma ray attenuation density measured on the Whole-Round Multisensor Logger (black circles) and wet bulk density measured on discrete samples using the mass/volume method (red circles). B. Grain density measured on discrete samples using the moisture and density (MAD) mass/volume method. C. Porosity determined using MAD Method C.
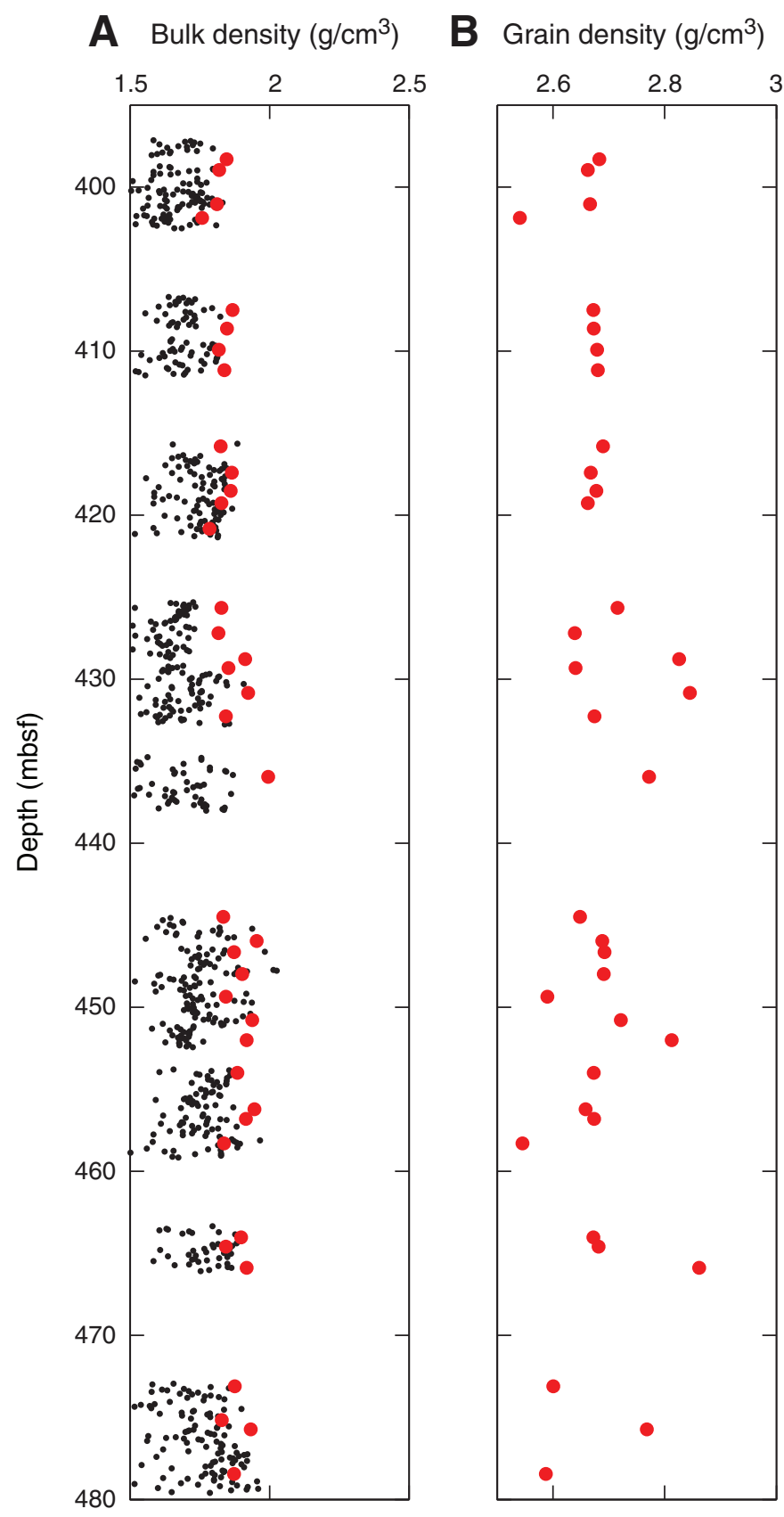

C Porosity (\%)

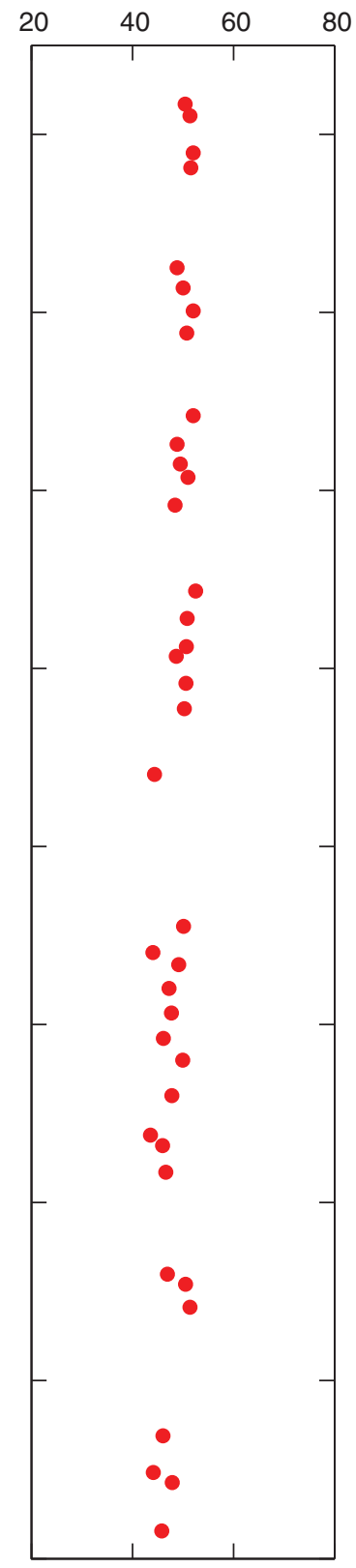


Figure F11. Plots of magnetic susceptibility as a function of depth, Site U1380. Volumetric magnetic susceptibility measurements were made on the Whole-Round Multisensor Logger and point measurements were made on the Section Half Multisensor Logger.

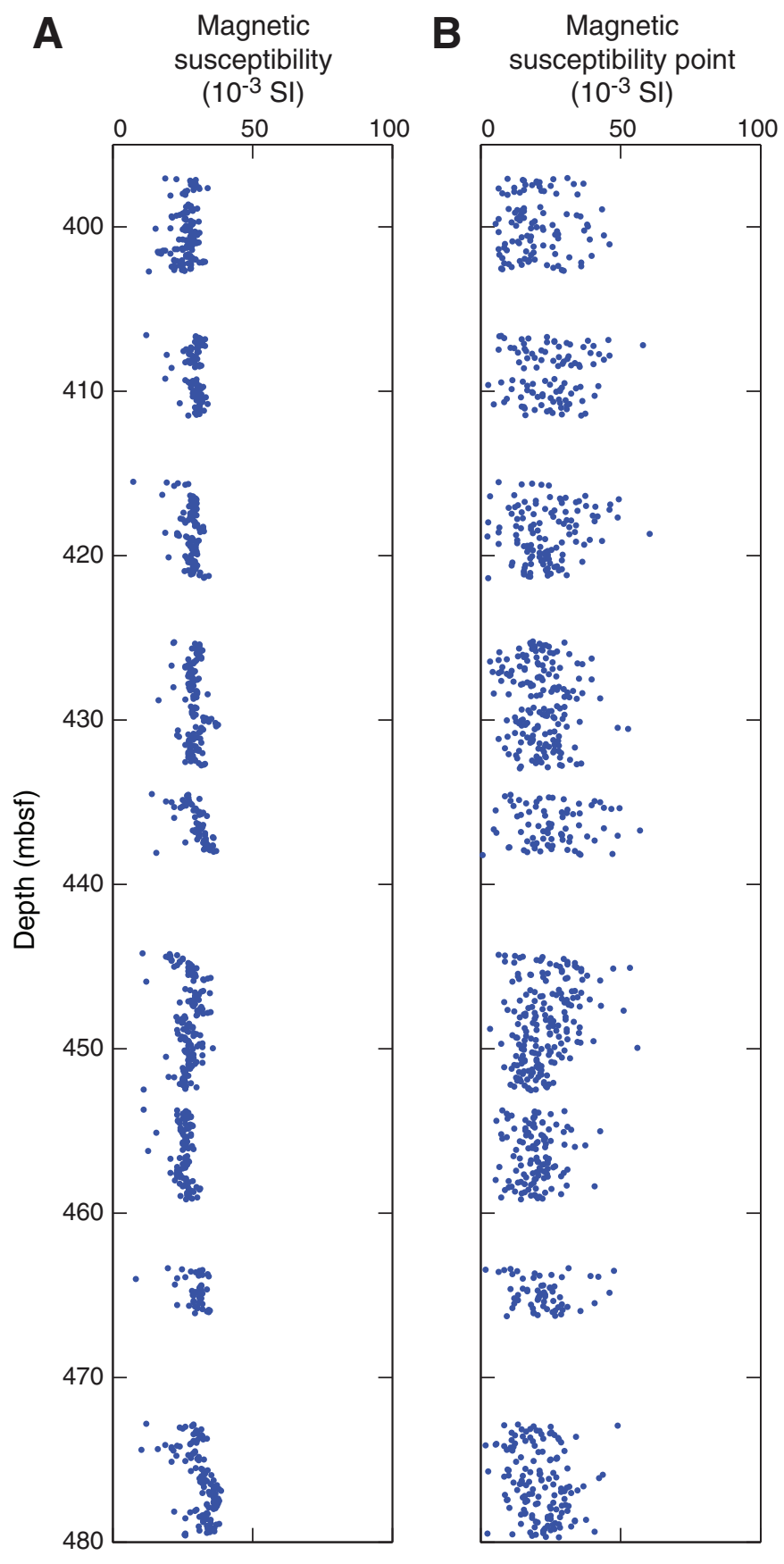


Figure F12. Plot of natural gamma radiation (NGR) as a function of depth, Site U1380.

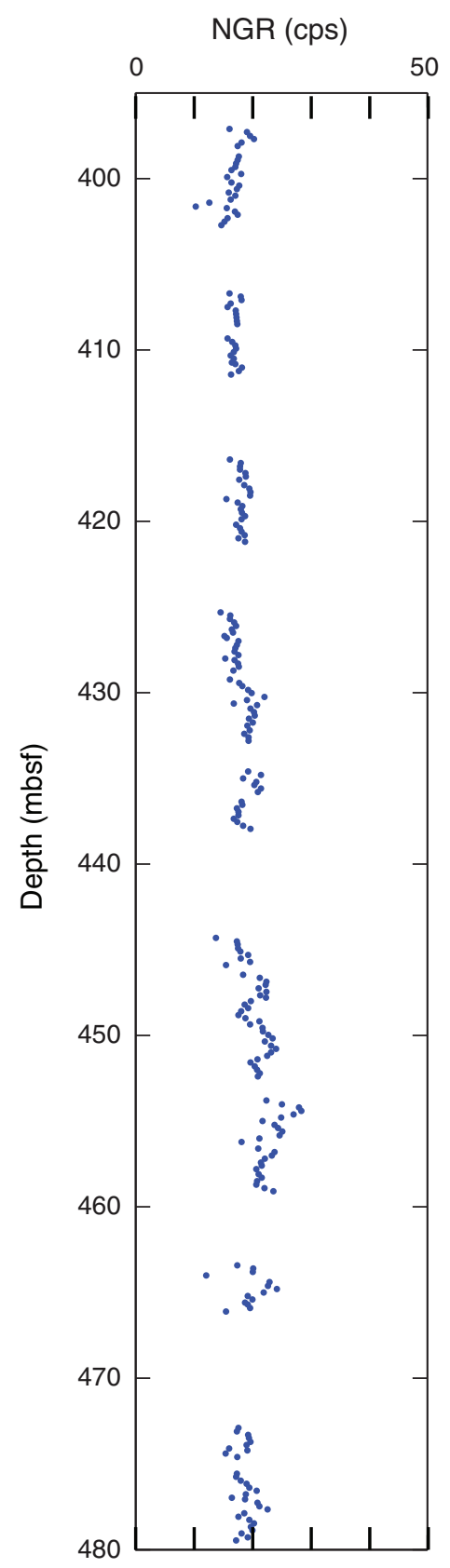


Figure F13. Plot of compressional wave velocity, Site U1380. P-wave velocity measured on discrete samples using the Section Half Measurement Gantry.

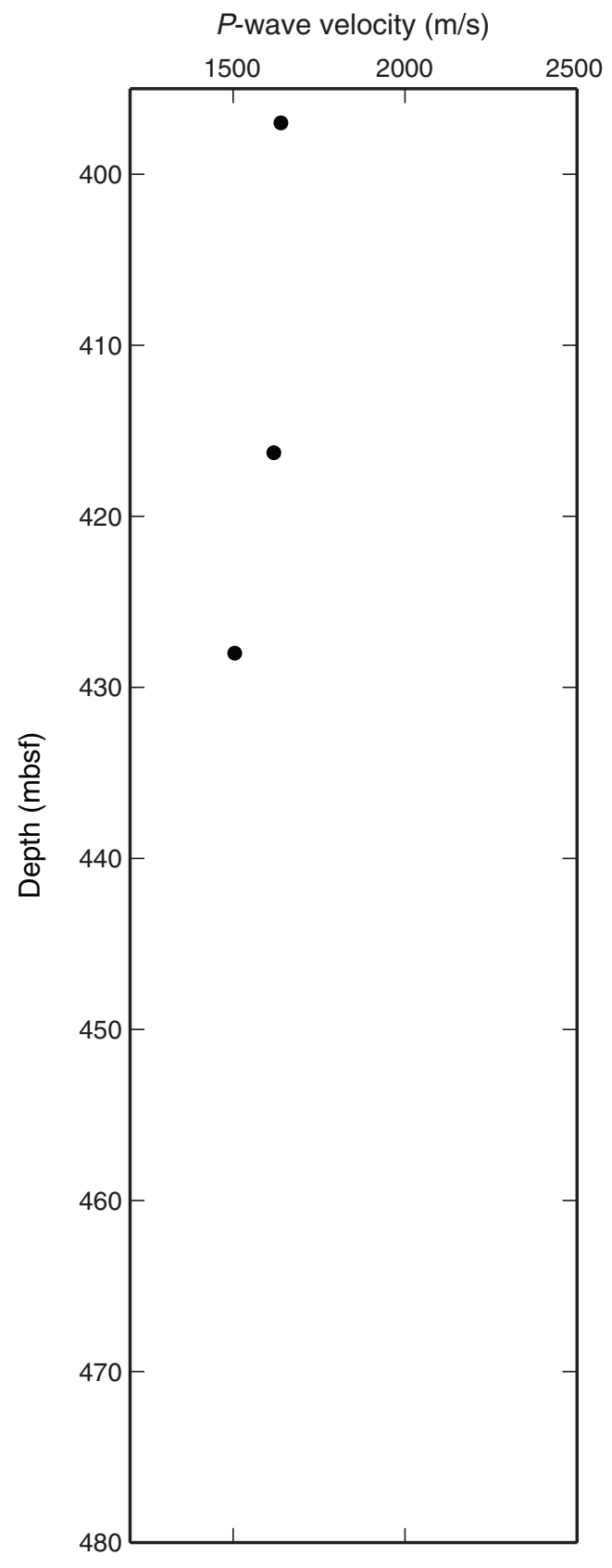


Figure F14. Plot of thermal conductivity data, Site U1380.

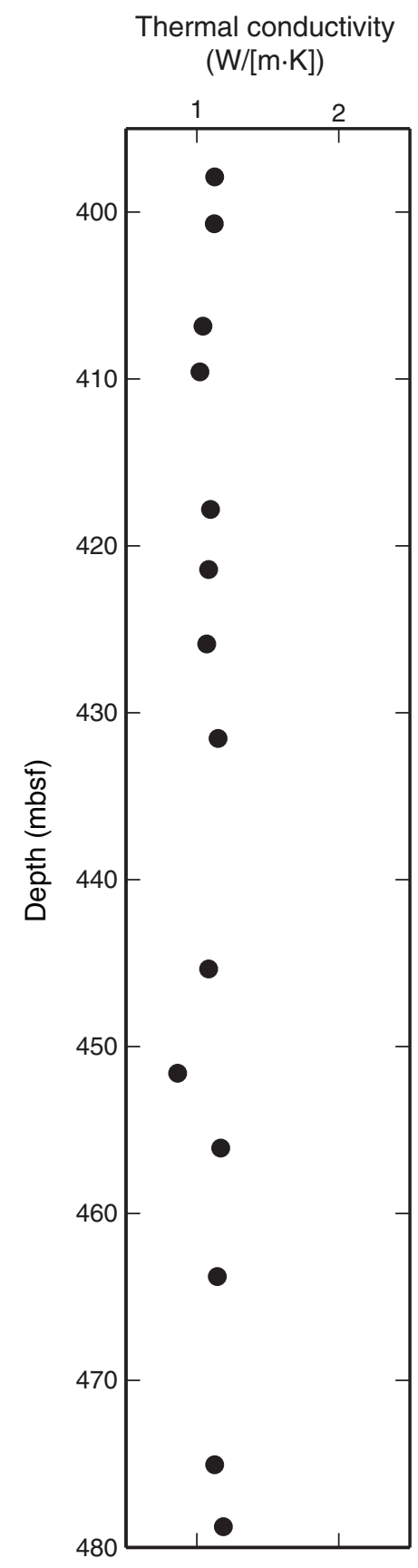


Figure F15. Plots of $\mathrm{L}^{*}, \mathrm{a}^{*}$, and $\mathrm{b}^{*}$ reflectance values vs. depth, Site U1380.

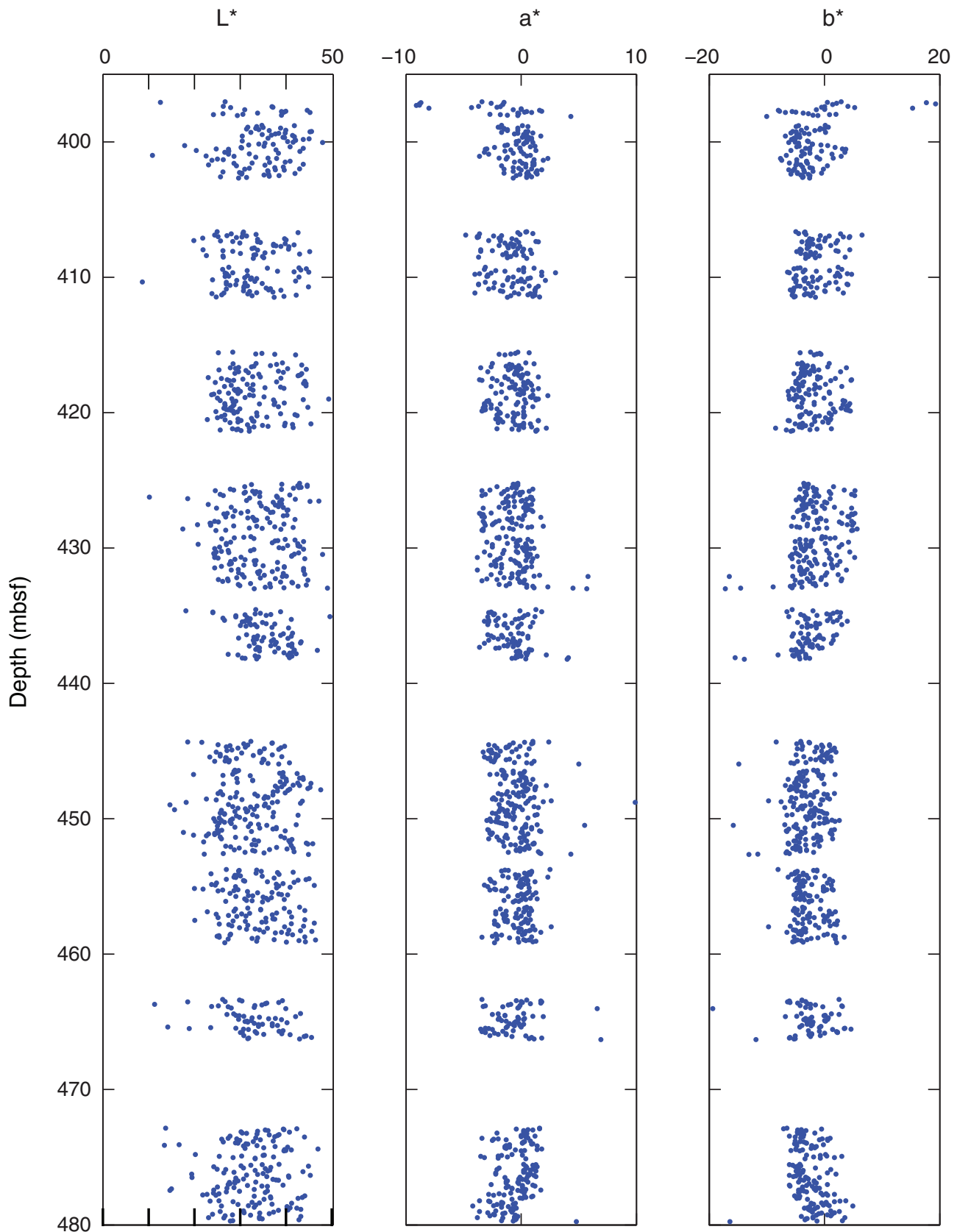


Figure F16. Plots of paleomagnetic measurements on archive sections of (A) natural remanent magnetization and (B) after $15 \mathrm{mT}$ AF demagnetization, Hole U1380A. Red stars indicate discrete samples.

A

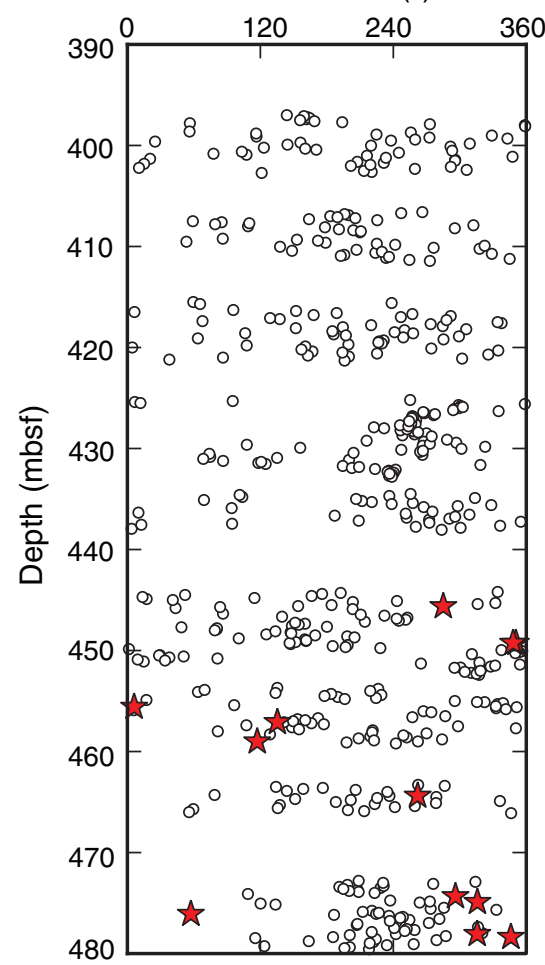

B

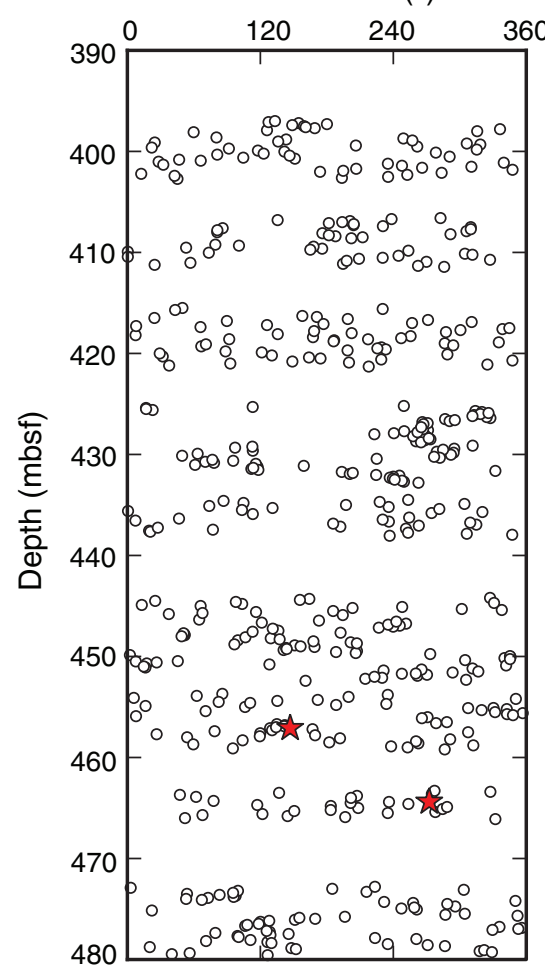

Inclination $\left({ }^{\circ}\right)$

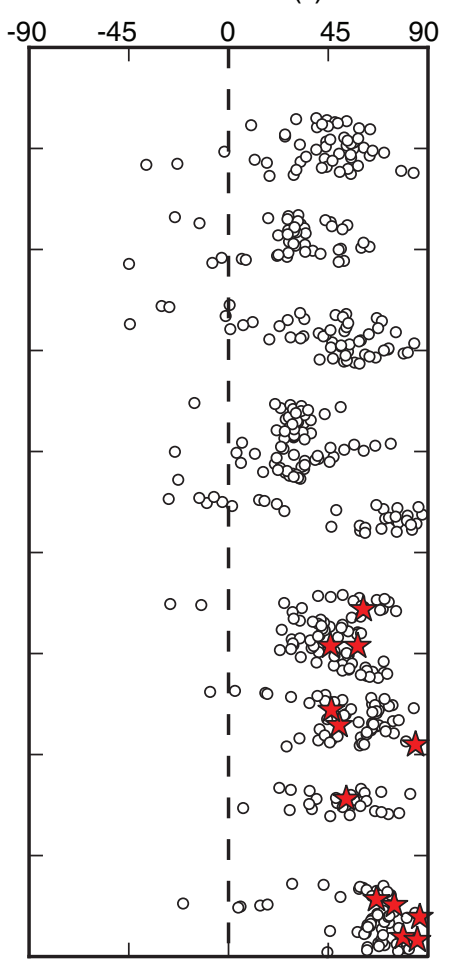

Inclination $\left({ }^{\circ}\right)$

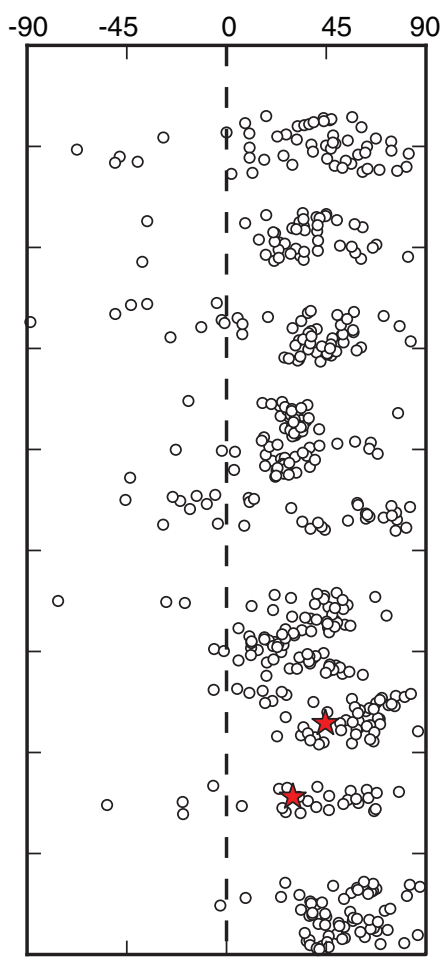

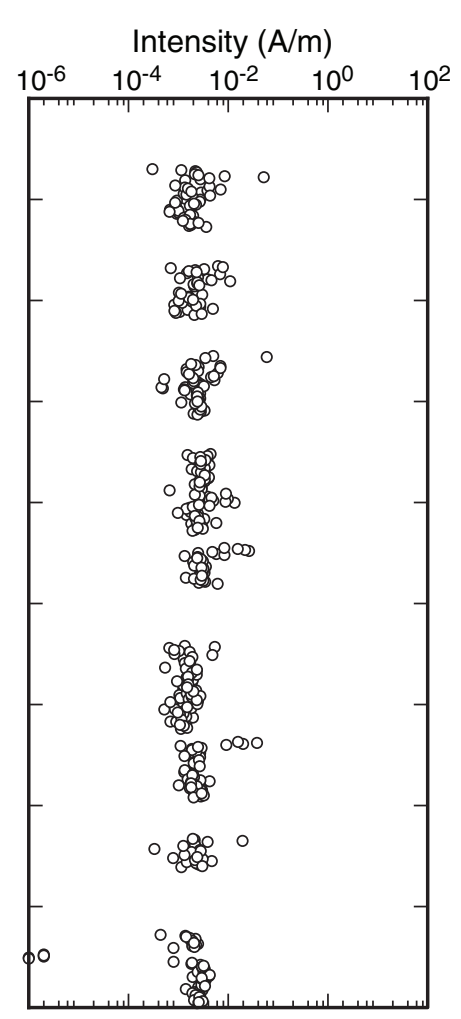

Intensity $(\mathrm{A} / \mathrm{m})$

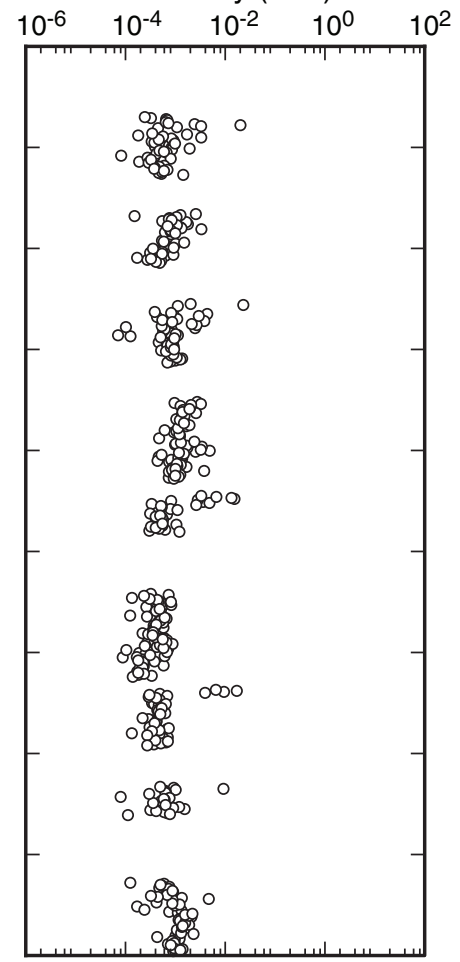


Figure F17. Representative vector endpoint diagrams (Zijderveld, 1967) of magnetization directions of discrete samples through stepwise AF demagnetization showing (A) complicated path at high field steps and (B) nearsingle component after removing the vertical overprint at $5 \mathrm{mT}$ demagnetization. Open squares and solid circles represent the projection of the magnetization vector endpoints onto the vertical and horizontal planes, respectively. $\mathrm{NRM}=$ natural remanent magnetization.

A Sample 334-U1380A-10R-3, $15-17 \mathrm{~cm}$

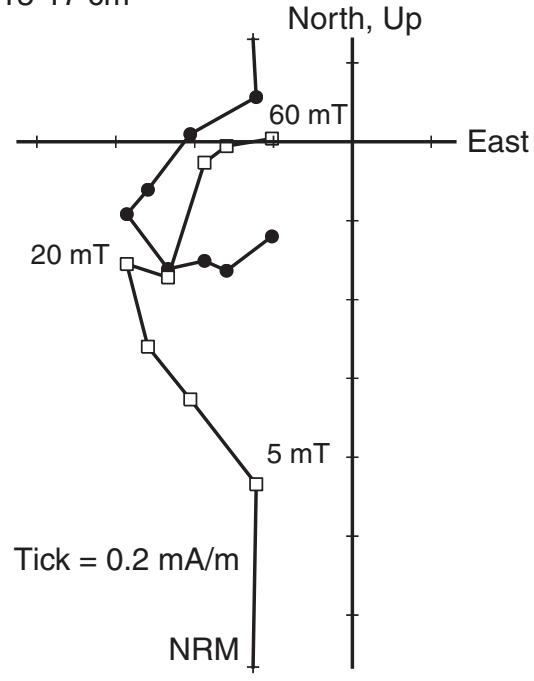

B Sample U1380A-9R-2, 8-10 cm

North, Up

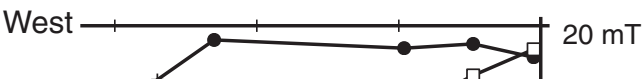


Figure F18. Diagrams of behavior of two discrete samples during stepwise thermal demagnetization. A, B. Magnetization intensity vs. temperature, showing steady decrease in natural remanent magnetization (NRM) intensity through progressive thermal demagnetization. C, D. Vector endpoint diagrams (Zijderveld, 1967) during thermal demagnetization. Characteristic remanent magnetization component is isolated after $150^{\circ} \mathrm{C} \mathrm{de-}$ magnetization. Open squares and solid circles represent the projection of the magnetization vector endpoints onto the vertical and horizontal planes, respectively.

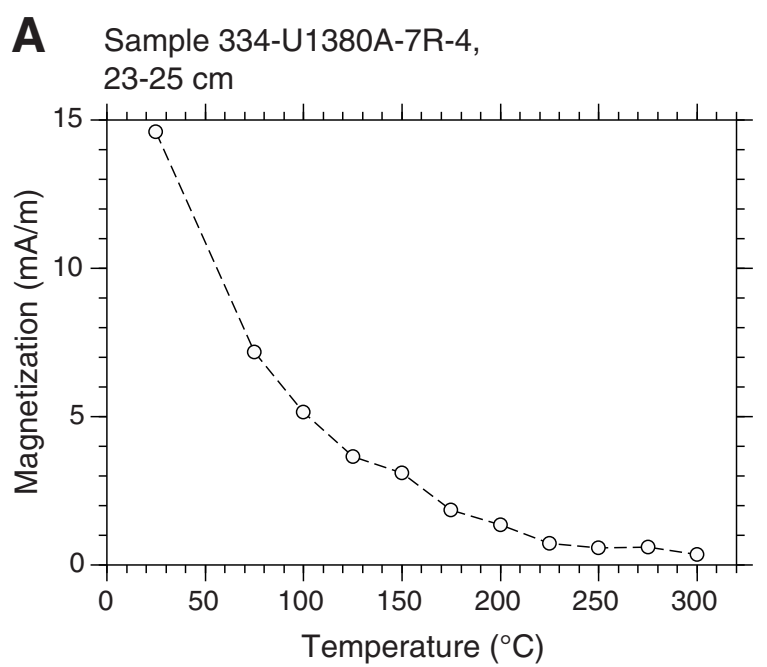

C Sample 334-U1380A-7R-4, $23-25 \mathrm{~cm}$

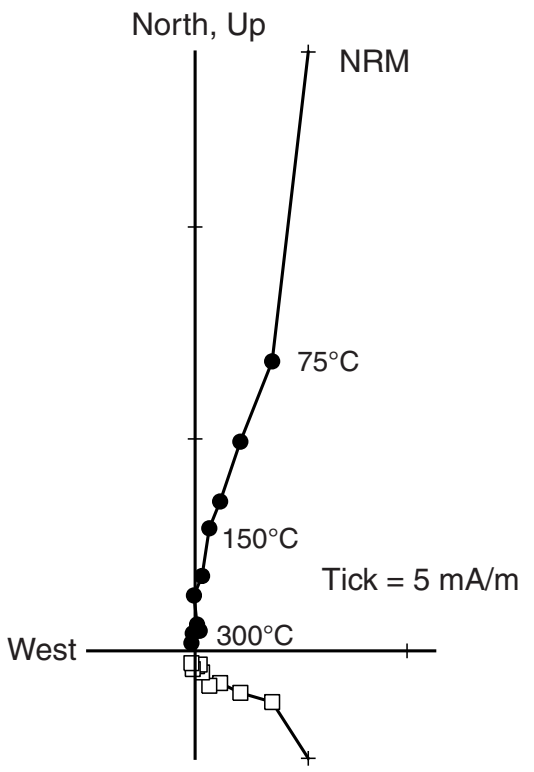

B Sample 334-U1380A-8R-1, 95-97 cm

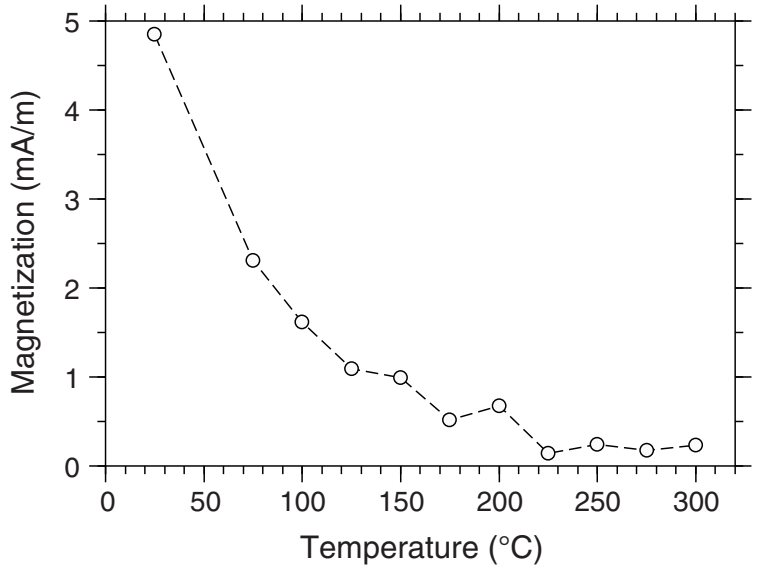

D Sample 334-U1380A-8R-1, 95-97 cm

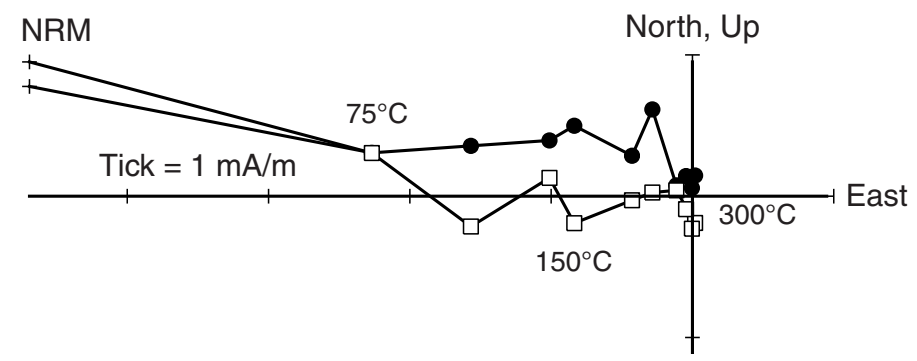


Table T1. Operations summary, Site U1380.

\begin{tabular}{|c|c|c|c|c|c|c|c|c|c|}
\hline $\begin{array}{c}\text { Hole U138 } \\
\text { Latitude: } \\
\text { Longitud } \\
\text { Time on } \\
\text { Seafloor } \\
\text { Distance } \\
\text { Water de } \\
\text { Total pen } \\
\text { Total len } \\
\text { Total cor } \\
\text { Recovery } \\
\text { Drilled in } \\
\text { Total nun }\end{array}$ & $\begin{array}{l}.9976^{\prime} \mathrm{N} \\
004.4032^{\prime} \\
\text { oh): } 46.6 \text { ( } \\
\text { pipe meas } \\
\text { een rig flo } \\
\text { drill pipe } \mathrm{n} \\
\text { in (drillin } \\
f_{\text {c cored int }} \\
\text { vered (m) } \\
61 \\
\text { I (m): } 397 . \\
\text { of cores: } 9\end{array}$ & $\begin{array}{l}0 \mathrm{~h}, 6 \mathrm{~A} \\
\text { nent be } \\
\text { nd sea } \\
\text { suremer } \\
\text { epth bel } \\
\text { l (m): } 8 \\
.37\end{array}$ & $\begin{array}{l}-2000 \mathrm{~h}, 8 \mathrm{Apr} \\
\text { rig floor, m DP } \\
\text { I (m): } 11.1 \\
\text { om sea level, } \mathrm{m} \\
\text { seafloor, } \mathrm{m} \text { DS }\end{array}$ & $\begin{array}{l}\text { ril 2011) } \\
\text { mbs): } 515.0 \\
\text { SF): } 482.4\end{array}$ & & & & & \\
\hline Core & $\begin{array}{l}\text { Date } \\
(2011)\end{array}$ & $\begin{array}{l}\text { Time } \\
(\mathrm{h})\end{array}$ & $\frac{\text { Depth D }}{\begin{array}{c}\text { Top of cored } \\
\text { interval }\end{array}}$ & $\frac{\text { DSF }(m)}{\begin{array}{c}\text { Bottom of } \\
\text { cored interval }\end{array}}$ & $\begin{array}{l}\text { Interval } \\
\text { advanced } \\
\text { (m) }\end{array}$ & 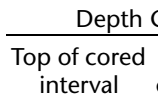 & $\frac{\operatorname{CSF}(\mathrm{m})}{\begin{array}{c}\text { Bottom of } \\
\text { cored interval }\end{array}}$ & $\begin{array}{l}\text { Length of core } \\
\text { recovered } \\
\text { (m) }\end{array}$ & $\begin{array}{l}\text { Recovery } \\
\text { (\%) }\end{array}$ \\
\hline \multicolumn{10}{|c|}{ 334-U1380A- } \\
\hline $2 \mathrm{R}$ & $08 \mathrm{Apr}$ & 0520 & 397.0 & 406.6 & 9.6 & 397.0 & 402.8 & 5.77 & 60 \\
\hline $3 R$ & $08 \mathrm{Apr}$ & 0620 & 406.6 & 415.5 & 8.9 & 406.6 & 411.6 & 4.95 & 56 \\
\hline $4 \mathrm{R}$ & $08 \mathrm{Apr}$ & 0715 & 415.5 & 425.2 & 9.7 & 415.5 & 421.6 & 6.07 & 63 \\
\hline $5 \mathrm{R}$ & $08 \mathrm{Apr}$ & 0815 & 425.2 & 434.5 & 9.3 & 425.2 & 433.0 & 7.82 & 84 \\
\hline $\begin{array}{l}6 \mathrm{R} \\
7 \mathrm{R}\end{array}$ & $\begin{array}{l}08 \mathrm{Apr} \\
08 \mathrm{Apr}\end{array}$ & $\begin{array}{l}1005 \\
1135\end{array}$ & $\begin{array}{l}434.5 \\
444.2\end{array}$ & $\begin{array}{l}444.2 \\
453.7\end{array}$ & $\begin{array}{l}9.7 \\
9.5\end{array}$ & $\begin{array}{l}434.5 \\
444.2\end{array}$ & $\begin{array}{l}438.3 \\
452.7\end{array}$ & $\begin{array}{l}3.77 \\
8.46\end{array}$ & $\begin{array}{l}39 \\
89\end{array}$ \\
\hline $8 \mathrm{R}$ & $08 \mathrm{Apr}$ & 1310 & 453.7 & 463.3 & 9.6 & 453.7 & 459.3 & 5.55 & 58 \\
\hline $9 \mathrm{R}$ & $08 \mathrm{Apr}$ & 1440 & 463.3 & 472.8 & 9.5 & 463.3 & 466.3 & 3.03 & 32 \\
\hline \multirow[t]{2}{*}{$10 \mathrm{R}$} & $08 \mathrm{Apr}$ & 1605 & 472.8 & 482.4 & 9.6 & 472.8 & 479.8 & 6.95 & 72 \\
\hline & & & \multicolumn{2}{|c|}{$\begin{array}{l}\text { Advanced total } \\
\text { Total interval cored }\end{array}$} & $\begin{array}{r}482.4 \\
85.4\end{array}$ & & & 52.37 & 55 \\
\hline
\end{tabular}

$\mathrm{DRF}=$ drilling depth below rig floor, $\mathrm{DSF}=$ drilling depth below seafloor, $\mathrm{CSF}=$ core depth below seafloor. $\mathrm{R}=\mathrm{RCB}$ core, $1=$ drilled interval. Time is Universal Time Coordinated.

Table T2. Calcareous nannofossil faunal distribution, Hole U1380A.

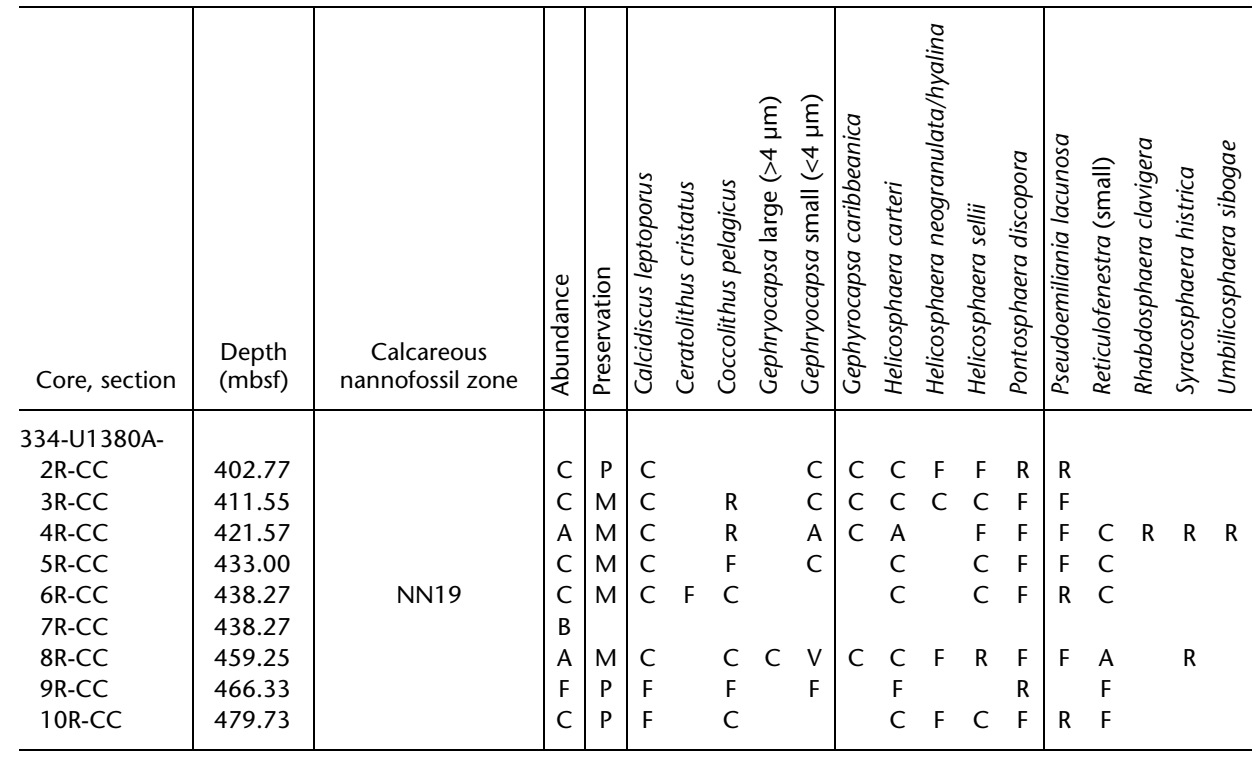

Abundance: $V=$ very abundant, $A=$ abundant, $C=$ common, $F=$ few, $R=$ rare, $B=$ barren. Preservation: $G=$ good, $M=$ moderate, $P=$ poor. See "Paleontology and biostratigraphy" in the "Methods" chapter (Expedition 334 Scientists, 2012a) for abundance and preservation definitions. 
Table T3. Benthic foraminiferal faunal distribution, Hole U1380A.

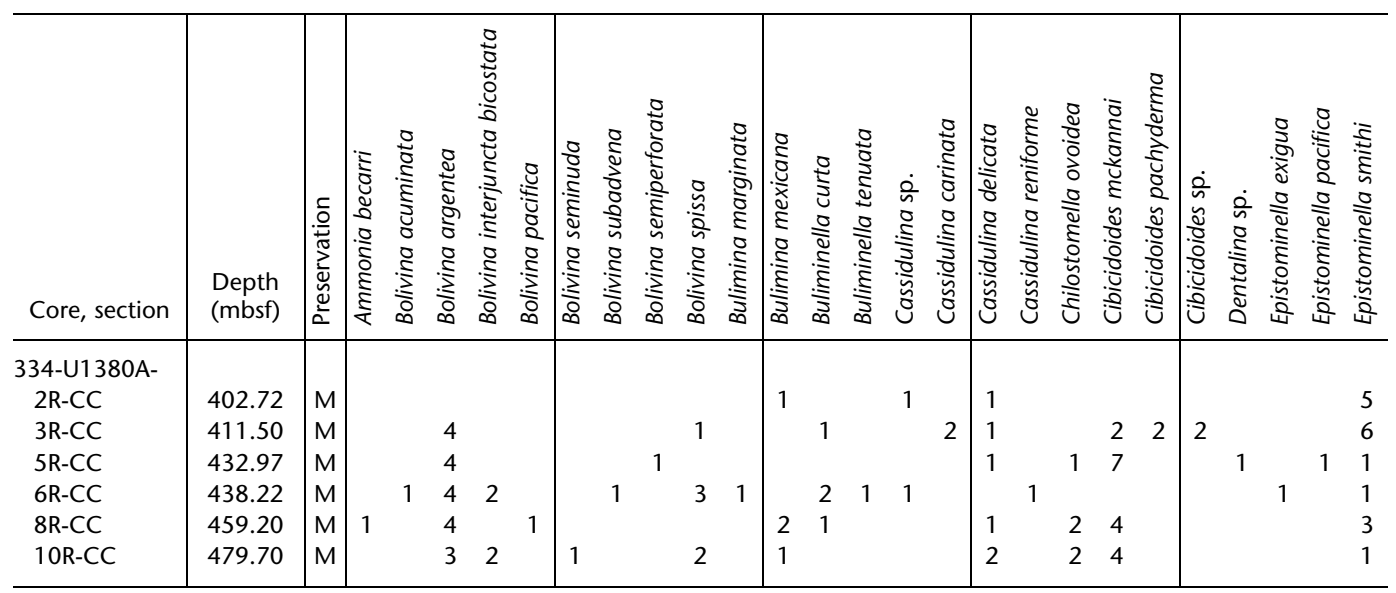

Preservation: $\mathrm{M}=$ moderate. See "Paleontology and biostratigraphy" in the "Methods" chapter (Expedition 334 Scientists, $2012 \mathrm{2}$ ) for preservation definitions. $\mathrm{PF}=$ planktonic foraminifers, $\mathrm{BF}=$ benthic foraminifers.

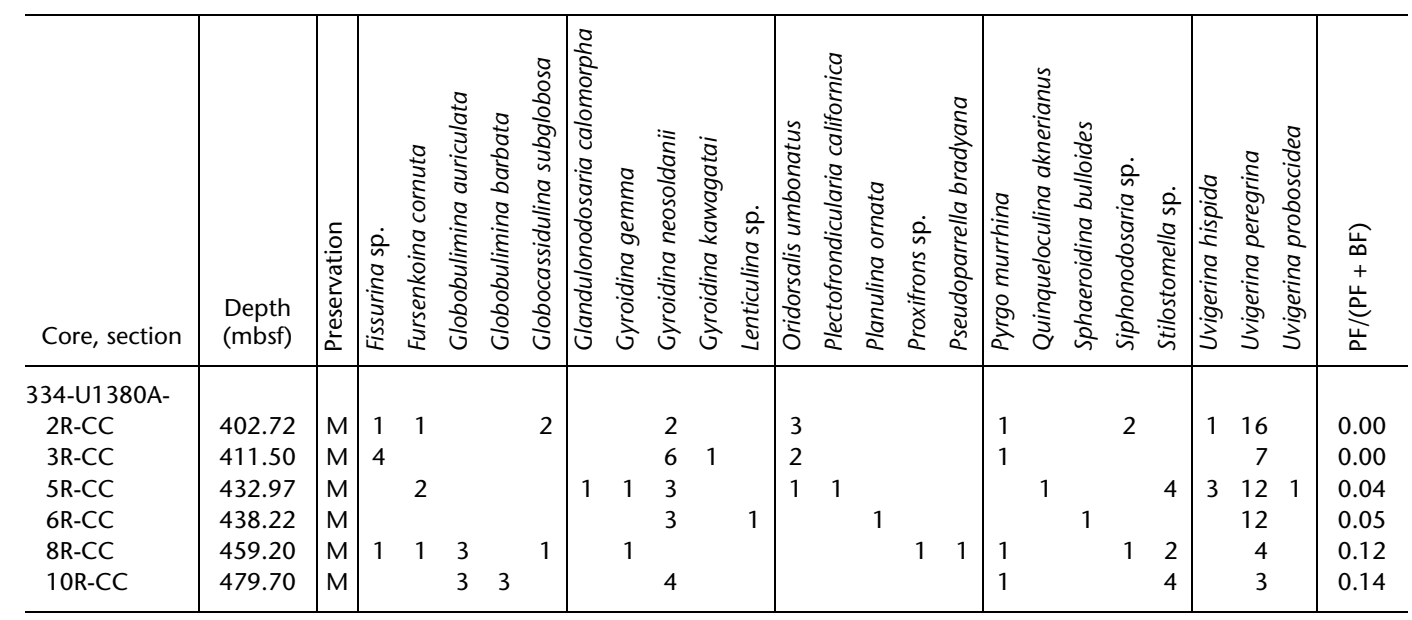

Table T4. Planktonic foraminiferal faunal distribution, Hole U1380A.

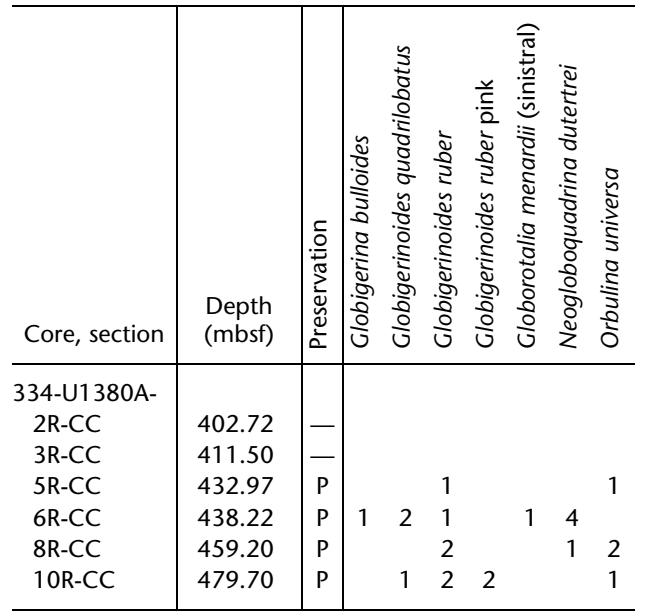

Preservation: $\mathrm{P}=$ poor, $-=$ no specimens. See "Paleontology and biostratigraphy" in the "Methods" chapter (Expedition 334 Scientists, 2012a) for preservation definitions. 
Table T5. Interstitial water chemistry, Hole U1380A.

\begin{tabular}{|c|c|c|c|c|c|c|c|c|c|c|c|c|c|c|}
\hline \multirow{2}{*}{$\begin{array}{l}\text { Core, section, } \\
\text { interval }(\mathrm{cm})\end{array}$} & \multirow{2}{*}{$\begin{array}{l}\text { Depth } \\
\text { (mbsf) }\end{array}$} & \multirow{2}{*}{$\begin{array}{c}\text { Volume } \\
(\mathrm{mL})\end{array}$} & \multirow[b]{2}{*}{ Salinity } & \multirow{2}{*}{$\begin{array}{l}\text { Alkalinity } \\
(\mathrm{mM})\end{array}$} & \multirow[b]{2}{*}{$\mathrm{pH}$} & \multirow{2}{*}{$\begin{array}{c}\mathrm{Cl} \\
(\mathrm{mM})\end{array}$} & \multicolumn{2}{|c|}{$\mathrm{SO}_{4}(\mathrm{mM})$} & \multirow{2}{*}{$\begin{array}{c}\mathrm{Ca} \\
(\mathrm{mM})\end{array}$} & \multirow{2}{*}{$\begin{array}{c}\mathrm{K} \\
(\mathrm{mM})\end{array}$} & \multirow{2}{*}{$\begin{array}{c}\mathrm{Mg} \\
(\mathrm{mM})\end{array}$} & \multirow{2}{*}{$\begin{array}{c}\mathrm{Na} \\
(\mathrm{mM})\end{array}$} & \multirow{2}{*}{$\begin{array}{c}\mathrm{Na} \\
(\mathrm{mM})\end{array}$} & \multirow{2}{*}{$\begin{array}{r}\mathrm{NH}_{4} \\
(\mathrm{mM})\end{array}$} \\
\hline & & & & & & & IC & ICP & & & & & & \\
\hline \multicolumn{15}{|l|}{ 334-U1380A- } \\
\hline 2R-1, 130-162 & 398.30 & 18.0 & 20.0 & 9.93 & 8.18 & 398 & - & 1.28 & 6.42 & 6.25 & 19.72 & 335 & 325 & 3.61 \\
\hline $3 R-2,83-123$ & 408.63 & 21.0 & 22.0 & 11.50 & 7.75 & 403 & 2.9 & 3.45 & 7.40 & 5.72 & 23.08 & 332 & 324 & 3.86 \\
\hline $4 R-1,29-63$ & 415.79 & 22.0 & 22.0 & 9.81 & 8.06 & 395 & 2.3 & 2.54 & 6.92 & 6.02 & 20.51 & 330 & 319 & 4.24 \\
\hline $5 R-3,78-113$ & 428.78 & 24.0 & 21.0 & 11.11 & 7.88 & 393 & 1.7 & 2.65 & 7.56 & 5.72 & 21.95 & 330 & 322 & 3.43 \\
\hline $6 \mathrm{R}-2,65-95$ & 435.95 & 6.5 & 20.0 & - & - & 386 & 1.7 & 1.72 & 7.82 & 6.13 & 20.24 & 335 & 328 & - \\
\hline 7R-2, 74-115 & 445.94 & 19.0 & 20.0 & 11.11 & 8.06 & 382 & - & 1.07 & 7.59 & 5.46 & 18.92 & 318 & 309 & 4.03 \\
\hline 8R-2, 109-139 & 456.20 & 5.0 & 20.0 & - & - & - & - & 1.59 & 7.82 & 5.61 & 18.24 & 319 & 313 & - \\
\hline 9R-1, 71-100 & 464.01 & 15.0 & - & - & - & 380 & 1.6 & 1.38 & 8.26 & 5.02 & 18.89 & 309 & 301 & 3.26 \\
\hline $10 \mathrm{R}-3,40-72$ & 475.15 & 22.0 & 21.0 & - & - & 396 & 3.9 & 2.83 & 9.19 & 5.93 & 18.67 & 329 & 325 & 3.64 \\
\hline
\end{tabular}

$\mathrm{IC}=$ ion chromatography, ICP $=$ inductively coupled plasma-atomic emission spectroscopy. $-=$ not measured.

Table T6. Gas geochemistry, Site U1380.

\begin{tabular}{|c|c|c|c|c|c|c|c|c|}
\hline $\begin{array}{c}\text { Average } \\
\text { depth } \\
\text { (mbsf) }\end{array}$ & $\begin{array}{c}\text { Sample } \\
\text { type }\end{array}$ & $\begin{array}{c}\mathrm{CH}_{4} \\
(\mathrm{ppmv})\end{array}$ & $\begin{array}{c}\mathrm{C}_{2} \mathrm{H}_{6} \\
(\mathrm{ppmv})\end{array}$ & $\begin{array}{c}\mathrm{C}_{3} \mathrm{H}_{6}+\mathrm{C}_{3} \mathrm{H}_{8} \\
\text { (ppmv) }\end{array}$ & $\begin{array}{l}\text { iso- } \mathrm{C}_{4} \mathrm{H}_{10} \\
\text { (ppmv) }\end{array}$ & $\begin{array}{l}n-\mathrm{C}_{4} \mathrm{H}_{10} \\
(\mathrm{ppmv})\end{array}$ & $\begin{array}{l}\text { iso- } \mathrm{C}_{5} \mathrm{H}_{12} \\
\text { (ppmv) }\end{array}$ & $\mathrm{CH}_{4} /\left(\mathrm{C}_{2} \mathrm{H}_{6}+\mathrm{C}_{3} \mathrm{H}_{8}\right)$ \\
\hline 398.1 & $N Z$ & $8,002.91$ & 12.34 & 2.27 & 0.00 & 0.00 & 0.00 & 547.66 \\
\hline 408.6 & $\mathrm{HS}$ & $8,240.66$ & 12.40 & 2.57 & 1.02 & 0.00 & 2.06 & 550.50 \\
\hline 415.7 & $\mathrm{HS}$ & $4,582.07$ & 6.98 & 1.39 & 0.55 & 0.00 & 0.91 & 546.88 \\
\hline 428.7 & $\mathrm{HS}$ & $11,012.46$ & 17.31 & 2.90 & 0.56 & 0.00 & 0.45 & 544.92 \\
\hline 435.9 & $\mathrm{HS}$ & $5,271.90$ & 6.96 & 2.88 & 1.06 & 0.42 & 1.04 & 535.49 \\
\hline 445.9 & $\mathrm{HS}$ & $3,346.67$ & 3.89 & 2.13 & 0.68 & 0.35 & 0.61 & 555.68 \\
\hline 456.2 & NZ & $7,655.84$ & 11.49 & 5.20 & 1.83 & 0.63 & 1.49 & 458.77 \\
\hline 465.6 & $\mathrm{NZ}$ & $3,969.52$ & 4.76 & 2.44 & 0.96 & 0.00 & 0.64 & 551.80 \\
\hline 475.1 & NZ & $11,925.59$ & 15.69 & 7.33 & 3.45 & 0.76 & 2.34 & 517.99 \\
\hline
\end{tabular}

$\mathrm{HS}=$ headspace sample, $\mathrm{NZ}=$ sample preserved with $10 \% \mathrm{KCl}$ solution. 